\title{
Molecular Techniques as Alternatives of Diagnostic Tools in China as Schistosomiasis Moving towards Elimination
}

\author{
Chao Lv ${ }^{1,2}$, Wangping Deng ${ }^{1}\left(\mathbb{D}\right.$, Liping Wang ${ }^{3}$, Zhiqiang Qin ${ }^{1}$, Xiaonong Zhou ${ }^{1,2, *(\mathbb{C})}$ and Jing Xu ${ }^{1, *}$ \\ 1 National Institute of Parasitic Diseases, Chinese Center for Disease Control and Prevention (Chinese Center \\ for Tropical Diseases Research), NHC Key Laboratory of Parasite and Vector Biology, WHO Collaborating \\ Centre for Tropical Diseases, National Center for International Research on Tropical Diseases, \\ Shanghai 200025, China; lvchao@nipd.chinacdc.cn (C.L.); dengwp@nipd.chinacdc.cn (W.D.); \\ qinzq@nipd.chinacdc.cn (Z.Q.) \\ 2 School of Global Health, Chinese Center for Tropical Diseases Research, Shanghai Jiao Tong University School \\ of Medicine, Shanghai 200025, China \\ 3 Jiading District Center for Disease Control and Prevention, Shanghai 200025, China; wlpnln1@163.com \\ * Correspondence: zhouxn1@chinacdc.cn (X.Z.); xujing@nipd.chinacdc.cn (J.X.)
}

check for updates

Citation: Lv, C.; Deng, W.; Wang, L.; Qin, Z.; Zhou, X.; Xu, J. Molecular Techniques as Alternatives of Diagnostic Tools in China as Schistosomiasis Moving towards Elimination. Pathogens 2022, 11, 287. https://doi.org/10.3390/ pathogens 11030287

Academic Editors: Hannah Wei Wu and Lawrence S. Young

Received: 14 December 2021

Accepted: 21 February 2022

Published: 24 February 2022

Publisher's Note: MDPI stays neutral with regard to jurisdictional claims in published maps and institutional affiliations.

Copyright: (C) 2022 by the authors. Licensee MDPI, Basel, Switzerland. This article is an open access article distributed under the terms and conditions of the Creative Commons Attribution (CC BY) license (https:// creativecommons.org/licenses/by/ $4.0 /)$.

\begin{abstract}
Schistosomiasis japonica caused by the trematode flukes of Schistosoma japonicum was one of the most grievous infectious diseases in China in the mid-20th century, while its elimination has been placed on the agenda of the national strategic plan of healthy China 2030 after 70 years of continuous control campaigns. Diagnostic tools play a pivotal role in warfare against schistosomiasis but must adapt to the endemic status and objectives of activities. With the decrease of prevalence and infection intensity of schistosomiasis in human beings and livestock, optimal methodologies with high sensitivity and absolute specificity are needed for the detection of asymptomatic cases or light infections, as well as disease surveillance to verify elimination. In comparison with the parasitological methods with relatively low sensitivity and serological techniques lacking specificity, which both had been widely used in previous control stages, the molecular detection methods based on the amplification of promising genes of the schistosome genome may pick up the baton to assist the eventual aim of elimination. In this article, we reviewed the developed molecular methods for detecting S. japonicum infection and their application in schistosomiasis japonica diagnosis. Concurrently, we also analyzed the chances and challenges of molecular tools to the field application process in China.
\end{abstract}

Keywords: schistosomiasis japonica; elimination; diagnostic tools; molecular techniques

\section{Introduction}

The worldwide pandemic of COVID-19 made administrators of government and all residents aware of the enormous threat from infectious disease to public health safety and social-economic growth [1,2]. Being a widespread tropical disease, schistosomiasis is endemic in 78 countries, with at least 236.6 million people required preventive treatment in 2019 according to the data from WHO. There are three major types of schistosomiasis affecting human beings: schistosomiasis japonica, schistosomiasis mansoni, and schistsomiasis hamatobium. Schistosomiasis japonica caused by Schistosoma japonicum (S. japonicum) is distributed in China, the Philippines, and small pockets of Indonesia in Asia, whereas the other two kinds of schistosomiasis, caused by S. haematobium and S. mansoni, are mainly distributed in countries belonging to Africa and South America [3,4]. Schistosomes are remarkable parasites for being exquisitely adapted to their two-host life cycle, which involves a short period of substantive population booms in the molluscan intermediate host and a long sheltered life, including prodigious egg laying in definitive mammalian hosts [5]. Based on the insight and experience that blocking any stage of the life cycle of S. japonicum would interrupt the transmission, the detection of individual or worm carriers and 
infected snails with the intention of identifying sources of infection and risk environments is extremely vital in control activities [6,7].

Applying optimal methodologies for diagnosis adapted to the changing control situation is crucial to every aspect of schistosomiasis control. Parasitological tests, such as the miracidia hatching technique (MHT) and Kato-Katz method (KK), are recommended as the "gold" standard for schistosomiasis diagnosis, especially in situations with high prevalence, but they are highly likely to miss infection with light intensity from low prevalence areas [8,9]. That is to say, the insensitivity of etiological detection will lead to an underestimation of disease burden, even threatening the success of the national program and the ultimate goal of elimination [10]. Serological tests based on the immunological response of antigens and antibodies have been widely applied in preliminary screening of patients and disease surveillance in many endemic countries with schistosomiasis, owing to advantages such as low cost, ease of operation, independence of complicated and expensive equipment, etc. [11,12]. However, serological methods have often been criticized for being relatively non-specific, prone to cross-reaction with other parasitic diseases, and unable to distinguish past from current infections [13,14]. With the flourishing of gene and genome research, nucleic acid detection provides a new idea for the diagnosis of schistosomiasis, presenting advantages of higher sensitivity and overwhelming specificity over immunological tests $[13,15]$. They are also superior in identifying infection by different species of Schistosoma in cases of low-grade infection [16,17]. Better yet, nucleic acid detection-based methods could complete detection based on various samples, including snail tissue [18,19], environmental samples [20], sera, and stool [21,22]. Although most molecular techniques still require expensive infrastructure and highly accurate pretreatment of samples, such as DNA extraction, they are the most potential and valuable methods used for disease surveillance and verifying elimination in many countries with very low endemicity of schistosomiasis, especially with the development of isothermal amplification techniques $[23,24]$.

In this paper, we reviewed the existing diagnostic methods specially focused on schistosomiasis japonica, emphatically introducing the progress of nucleic acid detectionbased methods. We also analyzed the potential of the molecular techniques applied in the national control program and the challenges that exist to provide reference for related experts of diagnosis and policymakers.

\section{Schistosomiasis Japonica and the Agenda of China}

Schistosomiasis japonica is a zoonotic disease, with human beings and more than 40 mammalian definitive hosts identified thus far [3,4]. Although it is endemic in China, the Philippines and Indonesia, the strain of S. japonicum in China is more virulent, with a wide range of epidemic areas and a heavier disease burden than the parasite in the other two countries [25]. Schistosomiasis japonica was a great public health threat in the 1950s with around 12 million infected people mainly distributed in 12 provinces of China along the Yangtze River [26-28], where the climate and environment are highly suitable for the propagation of oncomelanade snails. Slightly different from the WHO NTD roadmap's three time-bound goals for the control or elimination of schistosomiasis, the control process was divided into four stages or three criteria, in order: infection control (prevalence $<5 \%$ in humans and animals), transmission control (prevalence $<1 \%$ in humans and animals), transmission interruption (zero infection in local residents, domestic animals and snails in five consecutive years), and elimination (zero infection in local residents, domestic animals and snails in another five consecutive years after transmission interruption) [29-31].

Nowadays, schistosomiasis japonica has been eliminated in many previous endemic regions due to the high priority over schistosomiasis control at the political level, nearly 70 years of continuous national control program and the effort of multi-sectoral experts and local residents, as well as the flourishing development of economy and technology in China [10,32-34]. Five provinces, Shanghai, Guangdong, Guangxi, Fujian, and Zhejiang, have been pioneers in schistosomiasis elimination [35,36]. In 2019, only 5 cases (5 out of 
$327,475)$ and 7 domestic animals (7 out of 134,978$)$ were found to be etiologically positive nationwide [37]. By 2020, only 15 of 450 previous endemic counties were maintained in the stage of transmission control due to their complicated environment and relatively retarded economy. However, interrupting the transmission and eventually eliminating schistosomiasis completely nationwide, which set the national strategic plan of Healthy 2030, has turned out to be difficult [33,38]. To accelerate the process of schistosomiasis elimination, optimal methodologies with high sensitivity and absolute specificity are needed for the detection of asymptomatic cases or light infections, as well as disease surveillance to verify elimination.

\section{Traditional Diagnostic Tools Applied in Schistosomiasis Control in China}

It cannot be exaggerated that diagnosis is the essential basis of schistosomiasis control for case identification and treatment, assessment of morbidity, and evaluation of control strategies, which are all dependent on the performance of diagnostic tests $[27,39]$. Two kinds of diagnostic methodologies, namely parasitological techniques mainly including KK and MHT $[40,41]$, and immunologic approaches based on detection of specific antibodies, were widely used in the national control program in China, accelerating the process of schistosomiasis control significantly [11,42].

\subsection{Parasitological Methods}

The KK method, which was originally developed in the mid-1950s, and MHT, based on the positive phototactic behavior of miracidia, are the most broadly used techniques in epidemiological surveys pertaining to schistosomiasis in China [43]. At the stage of morbidity control, especially in the 1950-1980 period, the parasitological methods were the most applicable to the field, featured by high prevalence and high infection intensity. In 1989 , with the first national survey of schistosomiasis japonica, direct stool examination of the KK method or MHT was still the recommended method to evaluate the prevalence of schistosomiasis [6,43]. Until now, the KK method and MHT have been the most accepted "gold" standard methods for identifying whether people or animals are infected [6,44]. Additionally, some studies indicated that multiple KK tests per sample, or increasing the collection frequency of stool samples, would increase the diagnostic sensitivity [45-47], and the MHT technique possessed higher sensitivity than the KK method due to the larger volume of stool tests received. Additionally, the combination of MHT and microscopic examination of filtered stool sediment would increase the detection rate [48].

\subsection{Immunologic Tests}

The immunological tests for schistosomiasis diagnosis also have a long history in China. The earliest immunologic test in China was the intradermal text (ID) recorded in 1936, and it was adapted for screening prior to further parasitological examination in the national general survey in the 1950s. Subsequently, a variety of immunologic techniques were applied to the national schistosomiasis control program, such as the circumoval precipitin test (COPT), indirect hemagglutination assay (IHA), the enzymelinked immunosorbent assay (ELISA), and some rapid diagnostic tests (RDTs). Nowadays, ID and COPT have been out of use due to their low specificity, while IHA is still widely used in most endemic areas of China. Currently, there are two IHA kits with high quality control accredited by the China Food and Drug Administration. In the 10-year World Bank Loan Project (WBLP), aiming to control the morbidity of schistosomiasis, immunological tests were used directly to determine the target of chemotherapy in areas of medium endemicity $(15 \%>$ prevalence $>3 \%)$ and low endemicity (prevalence $<3 \%$ ) [43]. In the second national survey of schistosomiasis in 2004, in China, the ELISA method was adopted as a screening tool followed by stool examination to understand the real infection status of schistosomiasis in human beings. With the achievement of infection control reached in 2008 and transmission control reached in 2015, a diagnostic strategy with primary immunodiagnostic screening followed by KK or MHT for antibody-positive individuals 
was widely used in the Chinese national control program and routine surveillance activities in sentinel sites [27].

\section{Molecular Methods Developed to Detect the Pathogen of Schistosomiasis}

With the goal of the national program shifting from the control of schistosomiasis to elimination, extremely sensitive and specific diagnostic tools are needed emergently to explore asymptomatic cases with light infection and verify transmission interruption or elimination [34,49]. With the development of genomics and genome data for parasites and the urgent demands, molecular diagnostic techniques based on nucleic acid detection have emerged as new hot spots [50]. Various polymerase chain reaction (PCR)-based parasite DNA detection assays, including conventional polymerase chain reaction (cPCR), nested PCR (nPCR), real-time quantitative PCR (qPCR), and droplet digital PCR (ddPCR), have stimulated much interest as alternative options due to their proven diagnostic accuracy and the ability to detect early pre-patient infections [51,52]. The emergence of isothermal amplification methods, such as loop-mediated isothermal amplification (LAMP) and recombinase polymerase amplification (RPA), solves the dilemma of costly instrument dependence on PCR-based methods. The molecular diagnostic techniques of schistosomiasis japonica and the year first reported in China are shown in Figure 1. Regrettably, we have not seen any product based on molecular techniques applied in the field on a large scale.
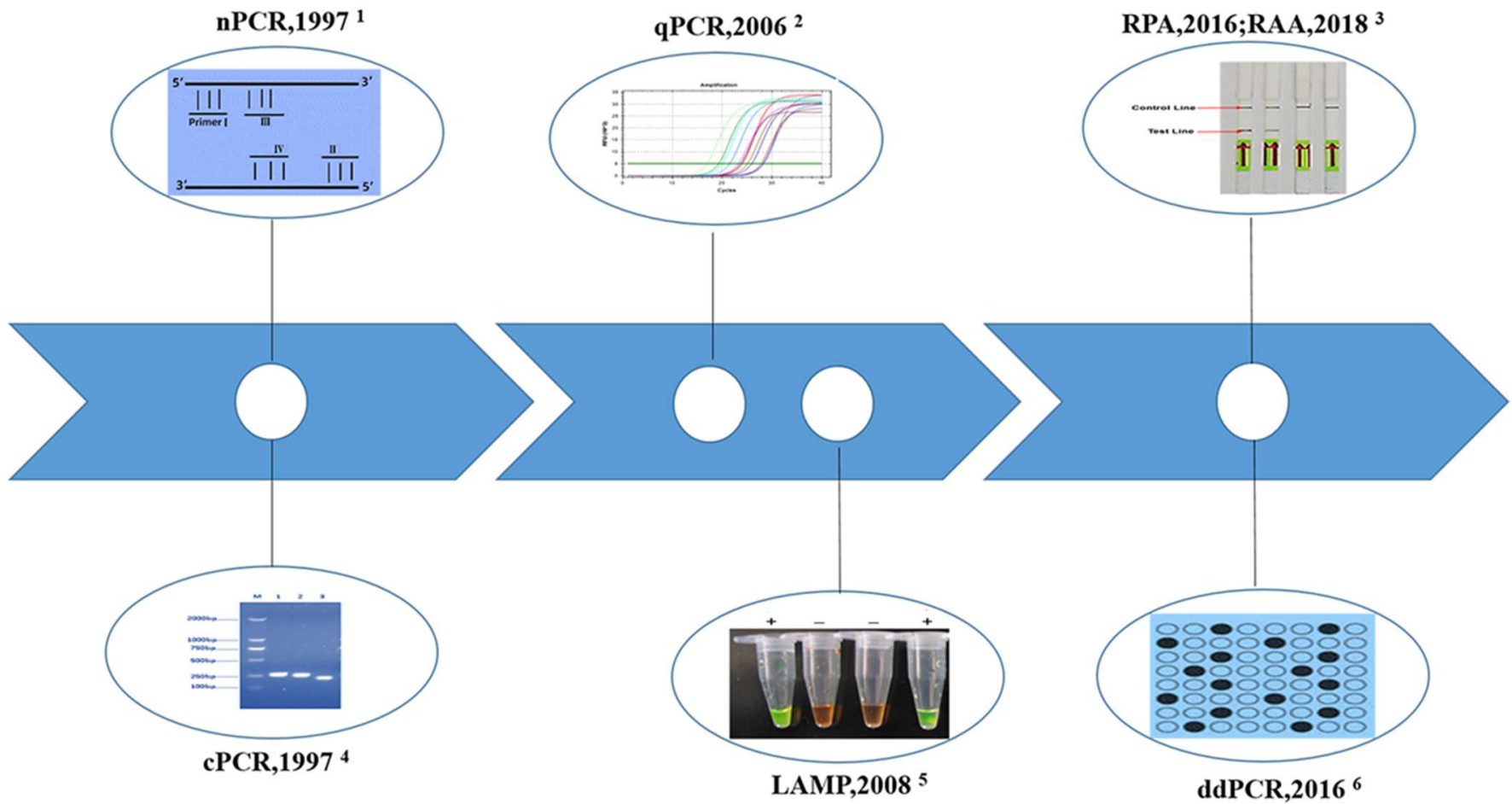

Figure 1. The molecular diagnostic techniques of schistosomiasis japonica and the year of first report in China. ${ }^{1} \mathrm{nPCR}$ is characterized by two pairs of primers, inner primer and outer primer; 2 qPCR can quantitatively and qualitatively analyze the initial template of samples by detecting the fluorescence signal corresponding to each cyclic amplification product in real time; ${ }^{3}$ The combination of RPA and lateral flow dipstick (LFD) for visual detection. Generally, visualization of control line and the test line is positive, and only the control line is negative; ${ }^{4} \mathrm{CPCR}$ determined positive or negative results by the size of the gel electrophoresis band; ${ }^{5}$ The combination of LAMP reaction with chemical dyes for visual detection. + positive reaction, - negative reaction; ${ }^{6}$ Dilute sample or samples DNA to the single molecule level and collect the fluorescence signal of a single reaction unit to achieve the absolute quantitative detection. Black spots: positive reaction units, blank spots: negative reaction units. 


\subsection{Conventional Polymerase Chain Reaction (cPCR)}

CPCR emerged in the 1980s with a specific ability to amplify a small amount of target DNA and was the first nucleic acid amplification test used in schistosomiasis japonica diagnosis [53]. The character of amplification of microscale DNA of different samples greatly improves the analytical ability, simplifies the diagnostic process, and increases the sensitivity $[14,16,51]$. Another obvious advantage of this technology is that the amplified products can be visualized by gel electrophoresis and verified by sequencing. So far, many CPCR methods for the diagnosis of schistosomiasis japonica targeting various genes from chromosomes and mitochondria extracted from different samples have been established (Table 1). One of the most important factors impacting the sensitivity of CPCR or other types of molecular detection assays is the abundance of the target sequences or biomarkers in the chromosome or mitochondrial genome $[16,51]$. The earliest reported PCR test for schistosomiasis diagnosis in China was based on the gene coding miracidium antigen named Sj5D [54-56]. Nowadays, the highly repetitive and conserved subunits of $18 \mathrm{~S}$ rRNA [57-60], 28S rRNA [18,61-63], cytochrome c oxidase subunit 1 (COX I) [64,65], and the repetitive sequences $\mathrm{SjR} 2$ (an RTE-like, non-long terminal repeat retrotransposon from S. japonicum) $[18,21,66-69]$ were the most common detection biomarkers. To evaluate the efficiency of established cPCR methods, several kinds of specimens, including genomic DNA (gDNA), pooled samples of snail and cercaria, and a mixture of eggs and feces, were employed. The lowest detection limit of cPCR established targeting a 607 base pair (bp) region of COX I can reach $10 \mathrm{fg}$ of gDNA, which is less than that of 1 egg or 1 cercariae [64].

cPCR also provided a potential tool for the early detection and therapy evaluation of $S$. japonicum infection. The cPCR assay using a 230-bp sequence of SjR2 established by Xia could detect $S$. japonicum DNA in sera at the first week post-infection, and it became negative at 10 weeks post-treatment in a rabbit model infected by S. japonicum [21]. Similarly, schistosome DNA can be detected from one day post infection using pooled urine samples of mice by COX I-cPCR [65]. Moreover, the CPCR assay was always used as a reference method to assess the efficacy of other established methods, not only molecular methods but also serological methods [60,70,71]. The cPCR assay targeting 254-bp size of COX I gene was used in the detection of human samples in highly endemic areas of the Philippines, and the results showed that schistosome DNA in the serum and urine of KK-positive subjects could be detected by COX I -cPCR with $100 \%$ sensitivity [65]. However, few studies have reported on detecting field samples by the CPCR method, which may largely be due to its dependence on specific equipment and relatively complicated producers.

Table 1. The target genes and sample types of established cPCR methods for schistosomiasis japonica.

\begin{tabular}{|c|c|c|c|c|c|c|}
\hline & Target Sequence & $\begin{array}{c}\text { No. of GenBank } \\
\text { Accession }\end{array}$ & $\begin{array}{l}\text { Fragment } \\
\text { Size (bp) }\end{array}$ & Detection Limit & Specimen & $\begin{array}{c}\text { Year of } \\
\text { Publication }\end{array}$ \\
\hline 1 & Sj5D & $\mathrm{N} / \mathrm{D}^{1}$ & 262 & 1 cercarial; & Animal tissue and blood & $\begin{array}{c}1997,1998 \\
{[54,55]}\end{array}$ \\
\hline 2 & Sj5D & $\mathrm{N} / \mathrm{D}$ & 262 & 10 fold diluted single cercarial DNA & Cercarial DNA & $2004[56]$ \\
\hline 3 & $18 \mathrm{~S}$ rRNA & DQ442999 & 469 & $40 \mathrm{pg}$ & gDNA & $2006[57]$ \\
\hline 4 & 18S rRNA & DQ̄442999 & 469 & 1 cercaria & Cercaria & 2008 [58] \\
\hline 5 & 18S rRNA & DQ̄442999 & 463 & $62.5 \mathrm{pg}$ & gDNA & $2010[59]$ \\
\hline 6 & 18S rRNA & FJ176682 & 157 & $\begin{array}{c}1 \text { cercaria in pooled } 10 \\
\text { non-infected snails; } \\
2 \text { eggs in } 100 \text { mg of non-infected } \\
\text { fecal sample }\end{array}$ & $\begin{array}{c}\text { Snail; } \\
\text { Fecal of mice }\end{array}$ & $2013[60]$ \\
\hline 7 & 28S rRNA & Z46504 & 405 & $100 \mathrm{fg}$ & gDNA & 2010 [18] \\
\hline 8 & $28 \mathrm{~S}$ rRNA & Z46504 & 607 & $15 \mathrm{pg}$ & gDNA & $2006[61]$ \\
\hline 9 & $28 \mathrm{~S}$ rRNA & Z46504 & 200 & N/D & Cattle fecal & 2017 [62] \\
\hline 10 & $28 \mathrm{~S}$ rRNA & EU835689.1 & 330 & $\mathrm{~N} / \mathrm{D}$ & Snail & 2018 [63] \\
\hline 11 & COX1 & AF215860 & 614 & $10 \mathrm{fg}$ & gDNA & 2010 [64] \\
\hline 12 & COX1 & AF215860 & 254 & $\mathrm{~N} / \mathrm{D}$ & Serum and urine & 2015 [65] \\
\hline 13 & $\mathrm{SjR} 2$ & AF412221 & 230 & $1 \mathrm{pg}$ & gDNA & 2010 [18] \\
\hline 14 & SjR2 & AF412221 & 230 & $0.8 \mathrm{pg}$ & gDNA & 2009 [21] \\
\hline 15 & SjR2 & $\mathrm{N} / \mathrm{D}$ & 176 & 1 cercariae & Cercariae & 2005 [66] \\
\hline 16 & SjR2 & AF412221 & 230 & 0.021 eggs & Egg DNA & $2007[67]$ \\
\hline 17 & SjR2 & AF412221 & 230 & 0.5 eggs $/ g$ of feces & Human feces & 2012 [68] \\
\hline 18 & $\mathrm{SjR} 2$ & N/D & 408 & 1 egg & Colon tissue & 2019 [69] \\
\hline 19 & $\begin{array}{l}\text { Mitochondrial } \\
\text { DNA gene }\end{array}$ & $\mathrm{N} / \mathrm{A}^{2}$ & $668 / 242$ & 0.3 eggs & Fecal of mice & $2005[72]$ \\
\hline
\end{tabular}

${ }^{1}$ N/D: Non-disclosed; ${ }^{2}$ N/A: Non-applicable. 


\subsection{Nested PCR (nPCR)}

The assay of nPCR, which can be considered a variant of $\mathrm{CPCR}$, requires two rounds of PCR amplification using two sets of primers, commonly called the outer primers and the inner primers [17]. nPCR is more sensitive and specific than CPCR because the probability is extremely low if the first round amplification produces an erroneous fragment; primer pairing and amplification will occur in the second round amplification using the wrong fragment [51]. The repetitive sequences of SjR2 and SjCHGCS19 (a new 303-bp sequence from non-long terminal repeat (LTR) retrotransposon) are the common biomarkers in $\mathrm{nPCR}$ assays $[73,74]$. The published literature showed that the detection limit of SjR2-nPCR stabilized at fg level with $10 \mathrm{fg}$ of minimum limit [75]. Validated by the schistosome-infected mice model [76], rabbit model [74,77], and domestic animals (goat and buffalo) [78], the SjR2-nPCR or SjCHGCS19-nPCR could all be used for early diagnosis of schistosomiasis, even light infection, showing positive results at 3 days post-infection through testing sera samples. For samples from humans with chronic schistosomiasis, the detection rate of 230bp SjR2-nPCR assay was $88.79 \%$ (95/107), significantly higher than that of the KK method $(69.16 \%, 74 / 107)$ [79]. The sensitivity of the SjR2-nPCR method established by Zhang et al. using 14 and 28 days post-infection buffalo samples was $92.30 \%(36 / 39)$ and $100 \%$ (39/39), while the specificity was $97.60 \%$ (41/42) [78]. Moreover, the SjCHGCS19-nPCR assay demonstrated $97.67 \%$ sensitivity for 43 patient serum samples and $96.07 \%$ specificity for 51 serum samples from healthy individuals [74]. In addition, an nPCR assay targeting the 420-bp fragment of the $\mathrm{Sj} \alpha 1$ gene, which is a short dispersal element retrotransposon gene with high copy and expression throughout the life cycle of schistosomes, could detect $0.1 \mathrm{fg}$ of gDNA and distinguish the infection status of snail $4 \mathrm{~h}$ post-infection [80]. However, the impressive performance of the detection efficacy of nPCR needed more verification.

\subsection{Real-Time Quantitative PCR ( $q P C R$ )}

The technique of the qPCR assay uses fluorescent labeled probes or double-stranded DNA-specific fluorescence dye to enable the continuous monitoring of amplicon (PCR product) formation throughout the reaction, thus allowing the quantification of PCR products by measuring fluorescence [81,82]. Compared with cPCR, qPCR has the following advantages: the amount of DNA in a sample can be measured using a standard curve, which can be determined by either spiking samples with a known amount of template or serial DNA dilutions; the qPCR procedures are streamlined with no need for an additional electrophoresis step to detect end-products of PCR, and the results can be preserved for a long time; and qPCR can utilize multiplex assays to detect multiple infections within a single clinical sample using specific probes and is preferred over CPCR in multiplex assays for having improved specificity by the use of probes [51,83].

The first reported qPCR assay for the detection of S. japonicum appeared in 2006, with mitochondrial NADH I as the target gene, and its detection limit could reach 1 egg per gram (EPG) fecal [84]. In the detection of 1,727 persons in field settings of Anhui Province, China, the prevalence (no. positive/no. examined) determined by NADH I-qPCR was $5.3 \%$, significantly higher than those of the hatching test (3.2\%) and Kato-Katz thick smear $(3.0 \%)$ [85]. In a field evaluation of qPCR assay conducted in Hunan, Anhui, Hubei, and Jiangxi provinces of China, the qPCR assay exhibited a high level of sensitivity ( $100 \%$ for humans, $96.83 \%$ for bovines) and specificity $(100 \%)$, and obtained a significantly higher prevalence in both the human $(11.06 \%$ for $\mathrm{qPCR}, 0.93 \%$ for MHT) and bovine samples (24.73\% for qPCR, $7.69 \%$ for MHT) [86]. The research conducted in the Philippines also showed similar trends, demonstrating that traditional copro-parasitological techniques underestimate the infection rate, signifying the advantages of qPCR for case finding and disease surveillance and monitoring [87-91]. Besides the gene of NADH I [85-95], several qPCR methods have been established targeting other genes, including COX I [96], 18S rRNA [97-101], ITS 2 [102], SjR2 [99,103,104], SjCHGCS20 [22], SjCHGC08270 [20,105], and Sjrh1.0 $[99,106]$ (Table 2). Those established qPCR methods have mostly completed the laboratory evaluation, but further validation should be conducted in field settings. Notably, 
the TaqMan qPCR assay targeting the COX I gene was developed to detect the environmental DNA (water samples) of S. japonicum, and its potential utility to schistosomiasis japonica surveillance in the Philippines was assessed. The results showed that the qPCR method could complement malacological surveys for monitoring schistosomes in endemic areas, especially those with a high risk of human infection [96].

Table 2. The target genes and application performance of qPCR assay for schistosomiasis japonica.

\begin{tabular}{|c|c|c|c|c|c|c|c|c|c|}
\hline & $\begin{array}{c}\text { Target } \\
\text { Sequence }\end{array}$ & $\begin{array}{l}\text { No. of } \\
\text { GenBank } \\
\text { Accession }\end{array}$ & $\begin{array}{l}\text { Fragment } \\
\text { Size (bp) }\end{array}$ & Detection Limit & $\begin{array}{c}\text { Sensitivity } \\
(\%)\end{array}$ & $\begin{array}{c}\text { Specificity } \\
(\%)\end{array}$ & Prevalence $^{1}$ & Specimen & $\begin{array}{c}\text { Year of } \\
\text { Publication }\end{array}$ \\
\hline 1 & NADH I & $\mathrm{N} / \mathrm{D}^{2}$ & 82 & $1 \mathrm{EPG}$ & $\mathrm{N} / \mathrm{A}^{3}$ & $\mathrm{~N} / \mathrm{A}$ & N/A & Human feces & 2006 [84] \\
\hline 2 & NADH I & $\mathrm{N} / \mathrm{D}$ & 75 & $1 \mathrm{EPG}$ & $\mathrm{N} / \mathrm{A}$ & $\mathrm{N} / \mathrm{A}$ & $\begin{array}{l}5.3 \% \\
11.06 \% \text { of }\end{array}$ & Human feces & 2009 [85] \\
\hline 3 & NADH I & $\mathrm{N} / \mathrm{D}$ & 82 & $5 \mathrm{EPG}$ & $100 / 96.83$ & 100 & $\begin{array}{l}\text { human; } \\
24.73 \% \text { of } \\
\text { bovines }\end{array}$ & $\begin{array}{l}\text { Buffalo and } \\
\text { human feces }\end{array}$ & 2018 [86] \\
\hline 4 & NADH I & $\mathrm{N} / \mathrm{D}$ & 82 & $1 \mathrm{EPG}$ & 100 & 100 & $51.5 \%$ & $\begin{array}{l}\text { Buffalo feces } \\
\text { buffalo and }\end{array}$ & 2010 [87] \\
\hline 5 & NADH I & $\mathrm{N} / \mathrm{D}$ & 82 & one egg; 14 pg & $95.25 / 94.0$ & 100 & $95.45 \%$ & $\begin{array}{l}\text { Human feces; } \\
\text { gDNA }\end{array}$ & 2012 [88] \\
\hline $\begin{array}{l}6 \\
7\end{array}$ & $\begin{array}{l}\text { NADH I } \\
\text { NADH I }\end{array}$ & $\begin{array}{l}\text { N/D } \\
\text { N/D }\end{array}$ & $\begin{array}{l}82 \\
82\end{array}$ & $\begin{array}{l}\text { N/A } \\
\text { N/A }\end{array}$ & $\begin{array}{l}\text { N/A } \\
\text { N/A }\end{array}$ & $\begin{array}{l}\mathrm{N} / \mathrm{A} \\
\mathrm{N} / \mathrm{A}\end{array}$ & $\begin{array}{l}87.50 \% \\
90.2 \%\end{array}$ & $\begin{array}{l}\text { Bovines feces } \\
\text { Human feces }\end{array}$ & $\begin{array}{c}2015[89] \\
2015[90,91]\end{array}$ \\
\hline 8 & NADH I & $\mathrm{N} / \mathrm{D}$ & 82 & $\mathrm{~N} / \mathrm{A}$ & $\mathrm{N} / \mathrm{A}$ & $\mathrm{N} / \mathrm{A}$ & $\mathrm{N} / \mathrm{A}$ & $\begin{array}{l}\text { Serum, urine and } \\
\text { fecal of pig model }\end{array}$ & 2008 [92] \\
\hline 9 & NADH I & $\mathrm{N} / \mathrm{D}$ & 82 & $5 \mathrm{EPG}$ & $\mathrm{N} / \mathrm{A}$ & $\mathrm{N} / \mathrm{A}$ & $\begin{array}{c}\mathrm{N} / \mathrm{A} \\
9.21 \% \text { of }\end{array}$ & Buffalo feces & 2009 [93] \\
\hline 10 & NADH I & $\mathrm{N} / \mathrm{D}$ & 82 & $\mathrm{~N} / \mathrm{A}$ & $\mathrm{N} / \mathrm{A}$ & $\mathrm{N} / \mathrm{A}$ & $\begin{array}{c}\text { rodents; } \\
18.37 \% \text { of } \\
\text { dogs; } 6.9 \% \text { of } \\
\text { goats }\end{array}$ & $\begin{array}{l}\text { Rodents, dogs and } \\
\text { goats feces }\end{array}$ & 2017 [94] \\
\hline 11 & NADH I & AF215860 & 75 & $\mathrm{~N} / \mathrm{A}$ & $\mathrm{N} / \mathrm{A}$ & $\mathrm{N} / \mathrm{A}$ & N/A & Organs & 2018 [95] \\
\hline 12 & COX I & N/D & 119 & N/A & $\mathrm{N} / \mathrm{A}$ & $\mathrm{N} / \mathrm{A}$ & N/A & Water samples & 2019 [96] \\
\hline 13 & 18S rRNA & AYl57226 & 81 & $6.15 \mathrm{pg}$ & $\mathrm{N} / \mathrm{A}$ & N/A & $48.0 \%$ & gDNA & 2008 [97] \\
\hline 14 & $18 \mathrm{~S}$ rRNA & AY157226 & 81 & $10 \mathrm{fg}$ & $\mathrm{N} / \mathrm{A}$ & $\mathrm{N} / \mathrm{A}$ & $\mathrm{N} / \mathrm{A}$ & gDNA & 2011 [98] \\
\hline 15 & $18 \mathrm{~S}$ rRNA & AY157226.1 & $\mathrm{N} / \mathrm{D}$ & $\begin{array}{c}20 \mathrm{fg} \\
4.3 \times 10^{2} \text { copies }\end{array}$ & $\mathrm{N} / \mathrm{A}$ & $\mathrm{N} / \mathrm{A}$ & $\mathrm{N} / \mathrm{A}$ & gDNA & 2011 [99] \\
\hline 16 & 18S rRNA & FJ176682 & 156 & $\begin{array}{l}\text { plasmid; } 0.4 \mathrm{fg} \\
\text { gDNA; } 10 \text { EPG; } \\
\text { one cercaria in } 10\end{array}$ & $\mathrm{~N} / \mathrm{A}$ & $\mathrm{N} / \mathrm{A}$ & $\mathrm{N} / \mathrm{A}$ & $\begin{array}{l}\text { Plasmids; gDNA; } \\
\text { mice feces; snail }\end{array}$ & 2013 [100] \\
\hline 17 & 18S rRNA & AY157226 & 280 & $\begin{array}{l}\text { pooled snails; } \\
10 \mathrm{fg}\end{array}$ & $\mathrm{N} / \mathrm{A}$ & $\mathrm{N} / \mathrm{A}$ & $\mathrm{N} / \mathrm{A}$ & gDNA & 2015 [101] \\
\hline 18 & ITS 2 & U22167 & 192 & $\begin{array}{l}1.42 \times 10^{2} \text { copies } \\
\text { plasmid; } 10 \mathrm{pg} \\
\text { gDNA; } 10 \mathrm{EPG}\end{array}$ & 100 & 100 & $\mathrm{~N} / \mathrm{A}$ & $\begin{array}{l}\text { Snail and mice } \\
\text { feces }\end{array}$ & 2011 [102] \\
\hline 19 & $\mathrm{SjR} 2$ & AF412221.1 & $\mathrm{N} / \mathrm{D}$ & $2 \mathrm{pg}$ & $\mathrm{N} / \mathrm{A}$ & $\mathrm{N} / \mathrm{A}$ & $\mathrm{N} / \mathrm{A}$ & gDNA & 2011 [99] \\
\hline 20 & SjR2 & AF412221 & $\mathrm{N} / \mathrm{D}$ & $\begin{array}{l}44.7 \text { copies } \\
\text { plasmid }\end{array}$ & $\mathrm{N} / \mathrm{A}$ & $\mathrm{N} / \mathrm{A}$ & $\mathrm{N} / \mathrm{A}$ & $\begin{array}{c}\text { Plasmids and sera } \\
\text { of rabbit }\end{array}$ & 2014 [103] \\
\hline $\begin{array}{l}21 \\
22 \\
23 \\
24\end{array}$ & $\begin{array}{c}\text { SjR2 } \\
\text { SjCHGCS20 } \\
\text { SjCHGC08270 } \\
\text { SjCHGC08270 }\end{array}$ & $\begin{array}{c}\text { N/D } \\
\text { FN356222.1 } \\
\text { AY812553 } \\
\text { AY812553 }\end{array}$ & $\begin{array}{l}\text { N/D } \\
\text { N/D } \\
85 \\
85\end{array}$ & $\begin{array}{c}\text { N/A } \\
\text { N/D } \\
\text { half of one cercaria } \\
\text { one cercaria }\end{array}$ & $\begin{array}{l}\mathrm{N} / \mathrm{A} \\
98.74 \\
93.75 \\
\mathrm{~N} / \mathrm{A}\end{array}$ & $\begin{array}{l}\text { N/A } \\
100 \\
\text { N/D } \\
\text { N/A }\end{array}$ & $\begin{array}{c}\mathrm{N} / \mathrm{A} \\
8.33 \\
\mathrm{~N} / \mathrm{A} \\
6.48\end{array}$ & $\begin{array}{c}\text { Water samples } \\
\text { Plasma of goat } \\
\text { N/A } \\
\text { Water samples }\end{array}$ & $\begin{array}{l}2021[104] \\
2020[22] \\
2008[20] \\
2011[105]\end{array}$ \\
\hline 25 & Sjrh1.0 & U92488.1 & $\mathrm{N} / \mathrm{D}$ & $2 \mathrm{fg}$ & $\mathrm{N} / \mathrm{A}$ & $\mathrm{N} / \mathrm{A}$ & $\mathrm{N} / \mathrm{A}$ & $\begin{array}{c}\text { gDNA and sera of } \\
\text { mice }\end{array}$ & 2011 [99] \\
\hline 26 & Sjrh1.0 & U92488.1 & $\mathrm{N} / \mathrm{D}$ & $2 \mathrm{fg}$ & $\mathrm{N} / \mathrm{A}$ & $\mathrm{N} / \mathrm{A}$ & $\mathrm{N} / \mathrm{A}$ & $\begin{array}{l}\text { gDNA and water } \\
\text { samples }\end{array}$ & 2011 [106] \\
\hline
\end{tabular}

${ }^{1}$ Prevalence: no. positive/no. examined; ${ }^{2}$ N/D: Non-disclosed; ${ }^{3}$ N/A: Non-applicable.

\subsection{Droplet Digital PCR (ddPCR)}

The technique of ddPCR can still be considered a 'new' technology in parasitology, including schistosomiasis. Owing to its sensitivity and absolute quantitative characteristics, ddPCR is a potential candidate to become an appealing new method for parasite detection and quantitative analysis in the future [107]. Weerakoon et al. developed a ddPCR duplex assay targeting SjR2 and NADH I for the detection of S. japonicum, which provides improved detection sensitivity and specificity. The assay was able to detect as little as $0.05 \mathrm{fg}$ of template DNA, and exhibited a high sensitivity for the detection of low levels of parasite DNA in stool, serum, urine, and saliva of mice model [108,109]. The ddPCR assay was also validated using clinical samples collected from 412 residents in a moderate-endemic area of schistosomiasis in the Philippines, proving its higher level of sensitivity obtained for human stool, serum, urine and saliva samples compared with the microscopy-based KK test $[110,111]$. Moreover, the capacity of ddPCR to quantify infection intensity has important public health implications for schistosomiasis control. Van Dorssen et al. determined the infection prevalence of S. japonicum in fecal samples of goats using 
the gene NADH I (46.4\% ddPCR vs. 6.9\% qPCR), showing that ddPCR was more sensitive than qPCR [93]. In general, the ddPCR technique with high sensitivity and specificity attracts increasing interest in its potential for clinical diagnosis and screening, and has the potential to be considered in schistosomiasis diagnosis as a complement to routine assays in schistosomiasis elimination programs.

\subsection{Loop-Mediated Isothermal Amplification (LAMP)}

The LAMP technique, which uses isothermal conditions to amplify DNA, is relatively simple, cost-effective, rapid, and more field-friendly compared with commonly used PCRbased methods [51,112]. Isothermal amplification does not require specific equipment, such as a thermocycler, electrophoresis apparatus, UV transilluminator, etc., while only a heating block or hot water bath is required for the reaction to progress $[83,113,114]$. The amplification results can be judged by precipitation turbidity of magnesium pyrophosphate or color reaction with the naked eye [115]. Hence, it is more suitable in resource-poor settings and grass-roots units. In addition, the four specific primers designed for six regions of target genes make the assay highly specific $[113,114]$. Of course, the LAMP technique has some shortcomings that need to be improved. It is complicated and time-consuming in the process of initial optimization with the use of multiple primers. Sometimes, the false-positive reaction is the fatal defect of the LAMP assay because of its high sensitivity $[116,117]$. Overall, the LAMP method is an extraordinary innovation trying to break through the restriction of equipment, and it has tremendous potential to apply in schistosomiasis control program for rapid screening, identification of transmission foci and environmental risk assessment.

A series of LAMP assays have been designed for schistosome-infected snail detection, schistosomiasis japonica diagnosis, and chemotherapy efficacy evaluation. The genes of CaBP (calcium-binding protein) [118,119], 28S rRNA [18,19,60], and SjR2 [120-125] were selected as the target sequence in the LAMP assay. Research has shown that the LAMP assay usually displays a higher detection rate than the conventional microscopy method for snail at different stages from 1 to 10 weeks post-infection [126]. 28S rRNA-LAMP was able to amplify the target band using DNA of a 1 day post-infection snail infected with one miracidium [18]. Nowadays, the LAMP assay has been applied to the surveillance of schistosoma infection of $O$. hupensis snail in national schistosomiasis sentinel sites in China $[60,127]$. In addition, a few studies have been conducted to evaluate the detection efficacy of LAMP for definitive hosts of S. japonicum. The SjR2-LAMP assay developed by $\mathrm{Xu}$ et al. was able to detect $S$. japonicum DNA in rabbit sera on the 3rd day post-infection. When LAMP was used to detect $S$. japonicum DNA in clinical serum samples $(n=152)$ from $S$. japonicum-infected patients and healthy persons, the sensitivity and specificity were $95.5 \%$ and $100 \%$, respectively [71]. Moreover, for 47 patients after treatment 3 months, 6 months, and 9 months, the negative conversion rate of $S$. japonicum DNA in patient sera increased from $23.4 \%$ to $61.7 \%$ to $83.0 \%$, respectively [123]. The above study demonstrated that the SjR2-LAMP method provides a useful and practical tool for the routine diagnosis and therapeutic evaluation of animals and human schistosomiasis.

\subsection{Recombinase Polymerase Amplification (RPA)}

Another isothermal amplification technology named RPA is a relatively new method that has experienced exponential growth in terms of publications, popularity, and applications since its first report in 2006 [128]. The central components of RPA mainly include DNA polymerase, DNA binding proteins, and recombinase. It is reported that RPA can operate at $37 \sim 42{ }^{\circ} \mathrm{C}$ and amplify as low as $1 \sim 10$ copies of target DNA to detectable levels in less than $20 \mathrm{~min}$. Therefore, the novel method is remarkable for its high sensitivity, simplicity, and extremely rapid amplification, as well as its operation at a low and constant temperature $[129,130]$. The RPA technique has been successfully integrated with different detection strategies, from end-point lateral flow strips to real-time fluorescent detection, among others, making this technique more user friendly, equipment-free, and facilitating 
the quantification of DNA [130]. In a meta-analysis of the diagnostic value of nucleic acid detection in schistosomiasis japonica, the isothermal amplification technique showed a relatively higher accuracy than the PCR-based amplification technique, and the sensitivity and specificity of the RPA method was higher than the LAMP assay [131]. However, RPA also has some disadvantages, such as the higher cost, carry-over contamination, and complicated optimization process $[129,130]$. Furthermore, due to the single source of RPA reagents or commercial kits, alternative products of the recombinase-aided isothermal amplification technique (RAA) have been developed in China [132-137].

The diagnostic method of RPA established for schistosomiasis japonica are concentrated after 2015, and the first retrievable literature was published in 2016 [23]. The visual detection method LFD-RPA (combination of RPA and lateral flow dipstick (LFD)) targeting SjR2 could detect $5 \mathrm{fg}$ of $S$. japonicum DNA and showed no cross-reaction with other parasites. The reaction could be finished within 15 20 min at a wide temperature range $\left(25-45^{\circ} \mathrm{C}\right)$. Furthermore, the LFD-RPA assay performed $92.86 \%$ sensitivity $(13 / 14), 100 \%$ of specificity $(31 / 31)$ and excellent diagnostic agreement with the KK method $(\mathrm{k}=0.947$, $\mathrm{Z}=6.36, p<0.001)$, indicating that the LFD-RPA assay has a great potency in field application [35]. The real-time RPA (RT-RPA) targeting SjR2 gene performed $0.9 \mathrm{fg}$ S. japonicum DNA detection limit, $100 \%$ sensitivity and specificity in detection of S. japonicum in stool samples from 30 infected patients and 30 healthy persons. The reaction could distinguish S. japonicum from other worms by measuring fluorescence using the Twista ${ }^{\mathrm{TM}}$ incubator block [24]. Deng et al. tried to establish a detection method for S. japonicum using the SjR2 gene by RPA combined with electrochemical (EC) DNA biosensor. The RPA-EC combinational detection method also exhibited high sensitivity ( $0.01 \mathrm{fg}$ detection limit), good specificity, and the ability to complete reaction within $30 \mathrm{~min}$ at $37^{\circ} \mathrm{C}$ [138]. Afterwards, the RPA or LFD-RPA assay for different biomarkers of 28S rRNA and SjCHGCS19 was developed, which also proved that the technology was sensitive, specific, fast, and convenient $[139,140]$.

\section{Prospect of Molecular Detection Methods in Schistosomiasis Diagnosis}

Unlike laboratory research, the costs for large-scale screening using the molecular detection method certainly constitute a major constraint. This is why the KK method is widely used for epidemiological surveys and recommended by WHO for surveillance and monitoring of schistosomiasis control programs $[29,141]$. However, in the current era featured by low endemicity of schistosomiasis, the asymptomatic cases or light infections would be missed by the KK method and MHT, resulting in significant underestimation of prevalence. There is also a consensus that diagnostic tools should be adapted when moving from morbidity control to elimination of infection [29]. It emphasizes that the accuracy of a given diagnostic technique may vary significantly with different schistosomiasis transmission levels. Antibody detection methods are indeed the most widely used nationwide in China, but this pattern of invasive sample collection may not be accepted in the future. Additionally, the detection results are prone to cause confusion and equivocal answers due to their low specificity. Therefore, in the case of reducing the cost, the molecular detection methods are greatly promising, at least in China. In fact, China is also promoting molecular detection methods in surveillance activities, such as LAMP for snail infection detection.

Among the available molecular detection methods, the methods of directly displaying results may be more suitable for the elimination stage, such as qPCR, LAMP, RPA, or RAA. Less procedures, especially casting off an additional electrophoresis step to detect PCR end-products, can be less time consuming and less labor intensive. The GPCR methods can also provide a measurement of infection intensity. The isothermal amplification methods, including LAMP and LFD-RPA, are more field-friendly for visualizing the results directly using the naked eye. The technique of RPA or RAA further reduces the reaction temperature and shortens the reaction time, which is more in line with the requirements of POCT (point of care test). However, the reagents of RPA are much more expensive than the two other methods, and the purchase of its reagents is harder than others for a source of monopoly. 
Overall, the above molecular detection methods should also be optimized and verified before large-scale application. For other molecular detection methods, they can be used as reference methods for laboratory testing, and are not suitable for field use. The key advantages, limitations, and relative costs of involved molecular methods are summarized in Table 3.

Table 3. Advantages, limitations, and prospects of large-scale application of different DNA diagnostics in China [51]. (The copyright permission of the Table 3 in the cited reference with modified form has been obtained from corresponding author of Professor Don McManus).

\begin{tabular}{|c|c|c|c|c|c|}
\hline $\begin{array}{l}\text { Method } \\
\text { Type }\end{array}$ & Advantages & Limitation & $\begin{array}{c}\text { Instrument } \\
\text { Cost }\end{array}$ & $\begin{array}{l}\text { Reagents } \\
\text { Cost } *\end{array}$ & $\begin{array}{c}\text { Prospect of } \\
\text { Large-Scale } \\
\text { Application ** }\end{array}$ \\
\hline cPCR & $\begin{array}{l}\text { Low cost and simple among the } \\
\text { molecular detection methods; } \\
\text { Can be multiplexed based on } \\
\text { different size domains of } \\
\text { the gene. }\end{array}$ & $\begin{array}{l}\text { Requires post-PCR processing } \\
\text { causing it to be more time } \\
\text { consuming and labor intensive; }\end{array}$ & $\$$ & $\$$ & $\Delta$ \\
\hline nPCR & $\begin{array}{l}\text { Improved the sensitivity and } \\
\text { specificity for using two sets } \\
\text { of primers }\end{array}$ & $\begin{array}{l}\text { Relatively complicated initial } \\
\text { optimization process; More time } \\
\text { consuming and labor intensive } \\
\text { than two rounds of cPCR } \\
\text { amplifications; Prone to } \\
\text { contamination with amplified } \\
\text { PCR products }\end{array}$ & $\$$ & $\$$ & $\Delta$ \\
\hline
\end{tabular}

\begin{tabular}{|c|c|c|c|c|c|}
\hline qPCR & $\begin{array}{l}\text { Higher sensitivity and } \\
\text { specificity when probes are } \\
\text { used; No post PCR processing } \\
\text { and less time consuming and } \\
\text { less labor intensive compared to } \\
\text { cPCR and nPCR; Can quantify } \\
\text { the amount of amplicons; } \\
\text { Lower potential laboratory } \\
\text { contamination }\end{array}$ & $\begin{array}{l}\text { Relatively complicated initial } \\
\text { optimization process; Requires } \\
\text { triplicate reactions to improve } \\
\text { the accuracy of final } \\
\text { calculations }\end{array}$ & $\$ \$$ & $\$$ & $\Delta \Delta$ \\
\hline ddPCR & $\begin{array}{l}\text { Higher sensitivity, specificity, } \\
\text { specifically when probes are } \\
\text { used; Can quantify the amount } \\
\text { of amplicons (absolute } \\
\text { quantification); Lower potential } \\
\text { laboratory contamination }\end{array}$ & $\begin{array}{l}\text { Requires specific and expensive } \\
\text { machinery for the initial } \\
\text { establishment; Relatively time } \\
\text { consuming and complicated } \\
\text { initial optimization process }\end{array}$ & $\$ \$ \$$ & $\$ \$$ & $\Delta$ \\
\hline LAMP & $\begin{array}{l}\text { Less equipment required; Can } \\
\text { visualize the end products } \\
\text { directly using naked eye }\end{array}$ & $\begin{array}{l}\text { Relatively time consuming and } \\
\text { complicated initial optimization } \\
\text { process; Prone to carryover } \\
\text { contamination }\end{array}$ & - & $\$$ & $\Delta \Delta \Delta$ \\
\hline RPA & $\begin{array}{l}\text { Less equipment required; End } \\
\text { products can be visualized on a } \\
\text { chip/lateral flow device; Has } \\
\text { great potential to be developed } \\
\text { as a point of care diagnostic tool }\end{array}$ & $\begin{array}{l}\text { Relatively complicated initial } \\
\text { optimization process; Prone to } \\
\text { contamination }\end{array}$ & - & $\$ \$ \$$ & $\Delta \Delta$ \\
\hline
\end{tabular}

\section{Chance, Challenges, and the Way Forward}

The pandemic of COVID-19 is really a catastrophe for human beings; however, this control progress has promoted the improvement of detection ability for disease control units and personnel, including those engaged in schistosomiasis control, especially for 
primary-level staff. In a questionnaire survey conducted in 36 countries or districts among the 12 schistosomiasis-endemic provinces in China, all CDC (Center for Disease Control and Prevention) or schistosomiasis control stations participated in the local campaign against COVID-19, and the participation rate of professionals previously engaged in schistosomiasis was $84.32 \%$ (936/1110) [38]. A few schistosomiasis control agencies have become a fixed point of coronavirus detection. Moreover, $9.51 \%$ of professionals from schistosomiasis control stations participated in virus detection, and the average working time reached 53 days, remarkably promoting the practice ability of molecular detection technologies [38]. Nowadays, most schistosomiasis control stations can independently carry out molecular detection assays, including PCR, qPCR, and isothermal amplification methods. Besides, the recognition for nucleic acid detection of residents and employees is getting higher with the widespread use of nucleic acid detection methods in COVID-19 control, providing an inside track for the field application of molecular detection methods of schistosomiasis, as long as methods with high sensitivity and accuracy are developed.

Although DNA amplification-based molecular diagnostic techniques for schistosomiasis japonica truly have made gratifying progress in recent 20 years, continuous efforts are still needed to establish accurate, field-deployable diagnostics, meeting the demands of national control programs and adapting to resource-limited and low prevalence endemic settings. It should also be noted that the current variable temperature and isothermal DNA amplification techniques present several important disadvantages in real application, including complicated DNA extraction, inseparable cryogenic storage, instability, carry-over contamination, and the unfriendliness of large-scale screening [51,113,116,117]. Nucleic acid extraction is a pivotal procedure, and it may be a bottleneck in DNA detection assays since the yield and quality of DNA directly affect the outcome of the amplification procedure. Meanwhile, nucleic acid purification is considered one of the important challenges preventing molecular diagnostics adoption from reaching the field, and the extraction procedure is also often the most expensive part of DNA-based diagnosis, particularly when using commercially available extraction kits [142,143]. Hence, simplifying available DNA extraction procedures to make them more convenient and less expensive is an urgent challenge to be solved. Currently, most molecular diagnostic reagents need cold chain transportation, and even some enzymes require more stringent temperature conditions $[143,144]$. Although the developed logistics can partly solve the transportation problem, long-distance transportation will undoubtedly increase the cost and waste of reagents, especially in resource-limited areas and remote areas. Nowadays, there are studies focused on ready-to-use reaction mixes stored at room temperature or at $4^{\circ} \mathrm{C}$ [145]. Stability is also a crucial factor in evaluating a method, especially in different conditions of carriage, storage, and experimental environments. Unfortunately, contrasting results occurred in some studies $[18,71,146]$, suggesting that the developed approaches should be evaluated in a multicenter manner. Carry-over contamination is another nerve-wracking problem, especially for isothermal amplification techniques with higher sensitivity [51,112]. Moreover, once the contamination appeared, it was very difficult to remove it in the same lab room. Hence, it is necessary to optimize the operation procedure to adapt to the resourcelimit lab. However, this optimization process is also time-consuming, complicated, and costly [116,117].

There are a set of criteria that the diagnostic methods should fulfill to be considered an ideal POCT or large-scale screening test. The criteria can be established by the acronym ASSURED, namely affordable, sensitive, specific, user-friendly, rapid, and robust, equipment free, and deliverable [147]. The isothermal amplification techniques, especially LAMP, already fulfill most of the requirements of the criteria of ASSURED. However, there is a very low probability that the isothermal amplification techniques (LAMP and RPA) can be developed to be completely equipment-free technologies; equipment dependence can be reduced and simplified to the fullest by combining with lateral flow dipsticks, microchips, and other lab-on-chip displays [148-150]. Actually, we have to admit that there are no significant changes in current molecular diagnostic protocols for schistosomiasis japon- 
ica, including the isothermal amplification method, although LAMP has been available since 2000.

\title{
7. Conclusions
}

Development and implementation of optimal methodologies for diagnosis is crucial in all aspects of schistosomiasis japonica control. Diagnostic tools with high sensitivity and specificity are needed as programs shift their goals from control to elimination in China [6,7]. Diagnostic technologies based on nucleic acid amplification can offset the deficiency of traditional parasitic methods. Meanwhile, the isothermal amplification techniques have made significant breakthroughs in breaking traditional laboratory boundaries by providing nucleic acid replication at constant temperatures [129]. It is gratifying that some glorious progress has been achieved, including the discovery of various biomarkers and the establishment of multiple kinds of detection techniques. Moreover, we have also tried to carry out the integration of LAMP in routine surveillance of schistosomiasis [127]. In the stage of schistosomiasis elimination, not only PCR-based detective methods but also isothermal amplification assays can be used as a vital supplement to traditional diagnostic methods of etiological and serological techniques. Certainly, simplifying and standardizing the existing molecular diagnostic methods and adjusting them to field application, especially the isothermal amplification method, are aspects that require continuous effort.

\begin{abstract}
Author Contributions: Conceptualization, J.X. and X.Z.; writing-original draft preparation, C.L.; writing-review and editing, W.D., L.W. and Z.Q. All authors have read and agreed to the published version of the manuscript.
\end{abstract}

Funding: Major national R\&D projects (2018ZX10101-002-002); Scientific research project of Shanghai Health Commission (20204Y0050).

Institutional Review Board Statement: Not applicable.

Informed Consent Statement: Not applicable.

Data Availability Statement: Not applicable.

Conflicts of Interest: The authors declare no conflict of interest.

\section{References}

1. Zhu, N.; Zhang, D.; Wang, W.; Li, X.; Yang, B.; Song, J.; Zhao, X.; Huang, B.; Shi, W.; Lu, R.; et al. A novel coronavirus from patients with pneumonia in china, 2019. N. Engl. J. Med. 2020, 382, 727-733. [CrossRef] [PubMed]

2. Case, J.B.; Winkler, E.S.; Errico, J.M.; Diamond, M.S. On the road to ending the covid-19 pandemic: Are we there yet? Virology 2021, 557, 70-85. [CrossRef] [PubMed]

3. Colley, D.G.; Bustinduy, A.L.; Secor, W.E.; King, C.H. Human schistosomiasis. Lancet 2014, 383, 2253-2264. [CrossRef]

4. $\quad$ Barnett, R. Schistosomiasis. Lancet 2018, 392, 2431. [CrossRef]

5. Nelwan, M.L. Schistosomiasis: Life cycle, diagnosis, and control. Curr. Ther. Res. Clin. Exp. 2019, 91, 5-9. [CrossRef]

6. Bergquist, R.; Yang, G.J.; Knopp, S.; Utzinger, J.; Tanner, M. Surveillance and response: Tools and approaches for the elimination stage of neglected tropical diseases. Acta Trop. 2015, 141, 229-234. [CrossRef]

7. Bergquist, R.; Zhou, X.N.; Rollinson, D.; Reinhard-Rupp, J.; Klohe, K. Elimination of schistosomiasis: The tools required. Infect. Dis. Poverty. 2017, 6, 158. [CrossRef]

8. Bergquist, R.; Johansen, M.V.; Utzinger, J. Diagnostic dilemmas in helminthology: What tools to use and when? Trends Parasitol. 2009, 25, 151-156. [CrossRef]

9. Knopp, S.; Speich, B.; Hattendorf, J.; Rinaldi, L.; Mohammed, K.A.; Khamis, I.S.; Mohammed, A.S.; Albonico, M.; Rollinson, D.; Marti, H.; et al. Diagnostic accuracy of kato-katz and flotac for assessing anthelmintic drug efficacy. PLoS Negl. Trop. Dis. 2011, 5, e1036. [CrossRef]

10. Rollinson, D.; Knopp, S.; Levitz, S.; Stothard, J.R.; Tchuem Tchuenté, L.A.; Garba, A.; Mohammed, K.A.; Schur, N.; Person, B.; Colley, D.G.; et al. Time to set the agenda for schistosomiasis elimination. Acta Trop. 2013, 128, 423-440. [CrossRef]

11. Hinz, R.; Schwarz, N.G.; Hahn, A.; Frickmann, H. Serological approaches for the diagnosis of schistosomiasis-A review. Mol. Cell Probes 2017, 31, 2-21. [CrossRef] [PubMed]

12. Chen, N.G.; Lin, D.D.; Xie, S.Y.; Wang, Q.Z.; Tang, L.; Liu, Y.M.; Zeng, X.J.; Liu, H.Y.; Huang, M.J.; Chen, H.G. Diagnostic efficiency of indirect hemagglutination assay kit for antibody detection of schistosomiasis japonica. Chin. J. Schistosomiasis Control 2011, 23, 377-380. (In Chinese) 
13. Hawkins, K.R.; Cantera, J.L.; Storey, H.L.; Leader, B.T.; de Los Santos, T. Diagnostic tests to support late-stage control programs for schistosomiasis and soil-transmitted helminthiases. PLoS Negl. Trop. Dis. 2016, 10, e0004985. [CrossRef] [PubMed]

14. Weerakoon, K.G.; Gobert, G.N.; Cai, P.; McManus, D.P. Advances in the diagnosis of human schistosomiasis. Clin. Microbiol. Rev. 2015, 28, 939-967. [CrossRef] [PubMed]

15. Lv, Z.; Wu, Z.; Zhang, L.; Ji, P.; Cai, Y.; Luo, S.; Wang, H.; Li, H. Genome mining offers a new starting point for parasitology research. Parasitol. Res. 2015, 114, 399-409. [CrossRef] [PubMed]

16. He, P.; Song, L.G.; Xie, H.; Liang, J.Y.; Yuan, D.Y.; Wu, Z.D.; Lv, Z.Y. Nucleic acid detection in the diagnosis and prevention of schistosomiasis. Infect. Dis. Poverty 2016, 5, 25. [CrossRef]

17. Chen, C.; Guo, Q.; Fu, Z.; Liu, J.; Lin, J.; Xiao, K.; Sun, P.; Cong, X.; Liu, R.; Hong, Y. Reviews and advances in diagnostic research on Schistosoma japonicum. Acta Trop. 2021, 213, 105743. [CrossRef]

18. Kumagai, T.; Furushima-Shimogawara, R.; Ohmae, H.; Wang, T.P.; Lu, S.; Chen, R.; Wen, L.; Ohta, N. Detection of early and single infections of Schistosoma japonicum in the intermediate host snail, Oncomelania hupensis, by PCR and loop-mediated isothermal amplification (LAMP) assay. Am. J. Trop. Med. Hyg. 2010, 83, 542-548. [CrossRef]

19. Tong, Q.B.; Chen, R.; Zhang, Y.; Yang, G.J.; Kumagai, T.; Furushima-Shimogawara, R.; Lou, D.; Yang, K.; Wen, L.Y.; Lu, S.H.; et al. A new surveillance and response tool: Risk map of infected Oncomelania hupensis detected by loop-mediated isothermal amplification (LAMP) from pooled samples. Acta Trop. 2015, 141, 170-177. [CrossRef]

20. Hung, Y.W.; Remais, J. Quantitative detection of Schistosoma japonicum cercariae in water by real-time PCR. PLoS Negl. Trop. Dis. 2008, 2, e337. [CrossRef]

21. Xia, C.M.; Rong, R.; Lu, Z.X.; Shi, C.J.; Xu, J.; Zhang, H.Q.; Gong, W.; Luo, W. Schistosoma japonicum: A PCR assay for the early detection and evaluation of treatment in a rabbit model. Exp. Parasitol. 2009, 121, 175-179. [CrossRef] [PubMed]

22. Guo, Q.; Chen, C.; Zhou, K.; Li, Y.; Tong, L.; Yue, Y.; Zhou, K.; Liu, J.; Fu, Z.; Lin, J.; et al. Evaluation of a real-time pcr assay for diagnosis of schistosomiasis japonica in the domestic goat. Parasites Vectors 2020, 13, 535. [CrossRef] [PubMed]

23. Sun, K.; Xing, W.; Yu, X.; Fu, W.; Wang, Y.; Zou, M.; Luo, Z.; Xu, D. Recombinase polymerase amplification combined with a lateral flow dipstick for rapid and visual detection of Schistosoma japonicum. Parasites Vectors 2016, 9, 476. [CrossRef] [PubMed]

24. Xing, W.; Yu, X.; Feng, J.; Sun, K.; Fu, W.; Wang, Y.; Zou, M.; Xia, W.; Luo, Z.; He, H.; et al. Field evaluation of a recombinase polymerase amplification assay for the diagnosis of Schistosoma japonicum infection in hunan province of China. BMC Infect. Dis. 2017, 17, 164. [CrossRef]

25. Rudge, J.W.; Webster, J.P.; Lu, D.B.; Wang, T.P.; Fang, G.R.; Basáñez, M.G. Identifying host species driving transmission of schistosomiasis japonica, a multihost parasite system, in China. Proc. Natl. Acad. Sci. USA 2013, 110, 11457-11462. [CrossRef]

26. Utzinger, J.; Zhou, X.N.; Chen, M.G.; Bergquist, R. Conquering schistosomiasis in china: The long march. Acta Trop. 2005, 96, 69-96. [CrossRef]

27. Xu, J.; Steinman, P.; Maybe, D.; Zhou, X.N.; Lv, S.; Li, S.Z.; Peeling, R. Evolution of the national schistosomiasis control programmes in the people's republic of china. Adv Parasitol. 2016, 92, 1-38. [CrossRef]

28. Zhou, X.N.; Wang, L.Y.; Chen, M.G.; Wu, X.H.; Jiang, Q.W.; Chen, X.Y.; Zheng, J.; Utzinger, J. The public health significance and control of schistosomiasis in china-Then and now. Acta Trop. 2005, 96, 97-105. [CrossRef]

29. Tchuem Tchuenté, L.A.; Rollinson, D.; Stothard, J.R.; Molyneux, D. Moving from control to elimination of schistosomiasis in sub-Saharan Africa: Time to change and adapt strategies. Infect. Dis. Poverty 2017, 6, 42. [CrossRef]

30. Xu, J.; Xu, J.F.; Li, S.Z.; Zhang, L.J.; Wang, Q.; Zhu, H.H.; Zhou, X.N. Integrated control programmes for schistosomiasis and other helminth infections in P.R. China. Acta Trop. 2015, 141, 332-341. [CrossRef]

31. Zhou, X.N.; Xu, J.; Lv, S.; Li, S.Z. Progress of the national programme and achievements of scientific researches on schistosomiasis elimination in china. Chin. J. Dis. Control Prev. 2019, 23, 749-753. (In Chinese) [CrossRef]

32. Zhang, L.J.; Dai, S.M.; Xue, J.B.; Li, Y.L.; Zhou, X.N. The epidemiological status of schistosomiasis in p. R. China after the world bank loan project, 2002-2017. Acta Trop. 2019, 195, 135-141. [CrossRef] [PubMed]

33. Xu, J.; Lv, S.; Cao, C.L.; Li, S.Z.; Zhou, X.N. Progress and challenges of schistosomiasis elimination in china. Chin. J. Schistosomiasis Control 2018, 30, 605-609. (In Chinese) [CrossRef]

34. Lei, Z.L.; Zhou, X.N. Eradication of schistosomiasis: A new target and a new task for the national schistosomiasis control porgramme in the People's Republic of China. Chin. J. Schistosomiasis Control 2015, 27, 1-4. (In Chinese)

35. Zhang, L.J.; Li, S.Z.; Wen, L.Y.; Lin, D.D.; Abe, E.M.; Zhu, R.; Du, Y.; Lv, S.; Xu, J.; Webster, B.L.; et al. The establishment and function of schistosomiasis surveillance system towards elimination in the People's Republic of China. Adv. Parasitol. 2016, 92, 117-141. [CrossRef]

36. Li-Juan, Z.; Zhi-Min, X.; Ying-Jun, Q.; Hui, D.; Shan, L.; Jing, X.; Shi-Zhu, L.; Xiao-Nong, Z. endemic status of schistosomiasis in people's republic of china in 2016. Chin. J. Schistosomiasis Control 2017, 29, 669-677. (In Chinese) [CrossRef]

37. Zhang, L.J.; Xu, Z.M.; Dang, H.; Li, Y.L.; Lü, S.; Xu, J.; Li, S.Z.; Zhou, X.N. Endemic status of schistosomiasis in People's Republic of China in 2019. Chin. J. Schistosomiasis Control 2020, 32, 551-558. (In Chinese) [CrossRef]

38. Guo, J.Y.; Zhang, L.J.; Cao, C.L.; Lü, S.; Xu, J.; Li, S.Z.; Zhou, X.N. Challenges of schistosomiasis control in china during the coronavirus disease 2019 (Covid-19) epidemic. Chin. J. Schistosomiasis Control 2020, 32, 511-516. (In Chinese) [CrossRef]

39. Collins, C.; Xu, J.; Tang, S. Schistosomiasis control and the health system in P.R. China. Infect. Dis. Poverty 2012, 1, 8. [CrossRef] 
40. Leuenberger, A.; Nassoro, T.; Said, K.; Fenner, L.; Sikalengo, G.; Letang, E.; Montresor, A.; Zhou, X.N.; Steinmann, P.; Marti, H.; et al. Assessing stool quantities generated by three specific kato-katz thick smear templates employed in different settings. Infect. Dis. Poverty 2016, 5, 58. [CrossRef]

41. Lin, D.D.; Liu, J.X.; Liu, Y.M.; Hu, F.; Zhang, Y.Y.; Xu, J.M.; Li, J.Y.; Ji, M.J.; Bergquist, R.; Wu, G.L.; et al. Routine kato-katz technique underestimates the prevalence of Schistosoma japonicum: A case study in an endemic area of the people's republic of China. Parasitol. Int. 2008, 57, 281-286. [CrossRef] [PubMed]

42. Xu, J.; Peeling, R.W.; Chen, J.X.; Wu, X.H.; Wu, Z.D.; Wang, S.P.; Feng, T.; Chen, S.H.; Li, H.; Guo, J.G.; et al. Evaluation of immunoassays for the diagnosis of Schistosoma japonicum infection using archived sera. PLoS Negl. Trop. Dis. 2011, 5, e949. [CrossRef] [PubMed]

43. Zhang, J.F.; Xu, J.; Bergquist, R.; Yu, L.L.; Yan, X.L.; Zhu, H.Q.; Wen, L.Y. Development and application of diagnostics in the national schistosomiasis control programme in the people's republic of China. Adv. Parasitol. 2016, 92, 409-434. [CrossRef] [PubMed]

44. Xu, J.; Li, S.Z.; Zhang, L.J.; Bergquist, R.; Dang, H.; Wang, Q.; Lv, S.; Wang, T.P.; Lin, D.D.; Liu, J.B.; et al. Surveillance-based evidence: Elimination of schistosomiasis as a public health problem in the peoples' republic of China. Infect. Dis. Poverty 2020, 9, 63. [CrossRef] [PubMed]

45. Xu, B.; Feng, Z.; Xu, X.J.; Hu, W. Evaluation of kato-katz technique combined with stool hatching test in diagnosis of schistosomiasis japonica. Chin. J. Schistosomiasis Control 2011, 23, 321-323. (In Chinese)

46. Lamberton, P.H.; Kabatereine, N.B.; Oguttu, D.W.; Fenwick, A.; Webster, J.P. Sensitivity and specificity of multiple kato-katz thick smears and a circulating cathodic antigen test for Schistosoma mansoni diagnosis pre- and post-repeated-praziquantel treatment. PLoS Negl. Trop. Dis. 2014, 8, e3139. [CrossRef]

47. Qian, M.B.; Zhuang, S.F.; Zhu, S.Q.; Deng, X.M.; Li, Z.X.; Zhou, X.N. Improving diagnostic performance of the kato-katz method for clonorchis sinensis infection through multiple samples. Parasites Vectors 2019, 12, 336. [CrossRef]

48. Zhu, H.Q.; Xu, J.; Zhu, R.; Cao, C.-L.; Bao, Z.-P.; Yu, Q.; Zhang, L.J.; Xu, X.L.; Feng, Z.; Guo, J.G. Comparison of the miracidium hatching test and modified kato-katz method for detecting Schistosoma japonicum in low prevalence areas of China. Southeast Asian J. Trop. Med. Public Health 2014, 45, 20-25.

49. Chen, J.; Xu, J.; Bergquist, R.; Li, S.Z.; Zhou, X.N. "Farewell to the god of plague": The importance of political commitment towards the elimination of schistosomiasis. Trop. Med. Infect. Dis. 2018, 3, 108. [CrossRef]

50. Schistosoma japonicum Genome Sequencing and Functional Analysis Consortium. The Schistosoma japonicum genome reveals features of host-parasite interplay. Nature 2009, 460, 345-351. [CrossRef]

51. Weerakoon, G.K.; Gordon, C.A.; McManus, D.P. DNA diagnostics for schistosomiasis control. Trop. Med. Infect. Dis. 2018, 3, 81. [CrossRef] [PubMed]

52. Utzinger, J.; Becker, S.L.; van Lieshout, L.; van Dam, G.J.; Knopp, S. New diagnostic tools in schistosomiasis. Clin. Microbiol. Infect. 2015, 21, 529-542. [CrossRef]

53. Mullis, K.; Faloona, F.; Scharf, S.; Saiki, R.; Horn, G.; Erlich, H. Specific enzymatic amplification of DNA in vitro: The polymerase chain reaction. Cold Spring Harb. Symp. Quant. Biol. 1986, 51, 263-273. [CrossRef] [PubMed]

54. Chen, Y.P.; Weng, X.H. Detection DNA of Schistosoma japonicum using PCR assay. Chin. J. Infect. Dis. 1997, 15, 203-206. (In Chinese)

55. Chen, Y.P.; Weng, X.H. The research of utilizing PCR to detect 5D gene of Schistosoma japonicum. Chin. J. Parasitol. Parasit. Dis. 1998, 26, 13-61. (In Chinese)

56. Zhou, J.; Tao, K.H.; Li, Y.X.; Qian, W.H.; Zhang, J.H.; Wang, Y.; Zhang, Z.S. Detection of Schistosomia japonicum 5D gene by polymerase chain reaction and genechip technique. Zhonghua Liu Xing Bing Xue Za Zhi 2004, 25, 154-157. (In Chinese) [PubMed]

57. Chen, J.H.; Wen, L.Y.; Zhang, X.Z.; Zhang, J.F.; Yu, L.L.; Hong, L.D. Development of a PCR assay for detecting Schistosoma japonicum-infected Oncomelania hupensis. Chin. J. Parasitol. Parasit. Dis. 2006, 24, 204-207. (In Chinese)

58. Li, H.J.; Liang, Y.S.; Dai, J.R.; Tao, Y.H.; Wang, W.; Qu, G.L.; Wei, J.Y. Homology of 18s small subunit ribosomal RNA gene among species and strains of schistosoma and sensitivity of PCR assay to detect single cercaria. Chin. J. Schistosomiasis Control 2008, 20, 418-422. (In Chinese)

59. Wang, T.A.; Shen, H.Y.; Shen, Y.X.; Wang, W.B.; Wang, B.J.; Liang, Y.S.; Hong-Xiang, Z. Establishment of PCR assay for detection of Schistosoma japonicum miracidium in water. Chin. J. Zoonoses 2010, 26, 562-564. (In Chinese)

60. Thanchomnang, T.; Tantrawatpan, C.; Intapan, P.M.; Sri-Aroon, P.; Limpanont, Y.; Limpanont, Y.; Lulitanond, V.; Janwan, P.; Sanpool, O.; Tourtip, S.; et al. Pyrosequencing for rapid molecular identification of Schistosoma japonicum and S. Mekongi eggs and cercariae. Exp. Parasitol. 2013, 135, 148-152. [CrossRef]

61. Sandoval, N.; Siles-Lucas, M.; Pérez-Arellano, J.L.; Carranza, C.; Puente, S.; López-Abán, J.; Muro, A. A new PCR-based approach for the specific amplification of DNA from different schistosoma species applicable to human urine samples. Parasitology 2006, 133, 581-587. [CrossRef] [PubMed]

62. Feng, T.; Qin, Z.Q.; Jing, X.U.; Zhou, J.; Qian, Y.J.; Zhu, H.Q.; Lv, S.; Cao, C.L.; Li, S.Z. Efficacy evaluation of a loop mediated isothermal amplification technique in detection of DNA of Schistosoma japonicum eggs in fecal samples. Chin. J. Parasitol. Parasit. Dis. 2017, 35, 230-234. (In Chinese)

63. Qin, Z.Q.; Xu, J.; Feng, T.; Lv, S.; Qian, Y.J.; Zhang, L.J.; Li, Y.L.; Lv, C.; Bergquist, R.; Li, S.Z.; et al. Field evaluation of a loop-mediated isothermal amplification (lamp) platform for the detection of Schistosoma japonicum infection in Oncomelania hupensis snails. Trop. Med. Infect. Dis. 2018, 3, 124. [CrossRef] 
64. Kato-Hayashi, N.; Kirinoki, M.; Iwamura, Y.; Kanazawa, T.; Kitikoon, V.; Matsuda, H.; Chigusa, Y. Identification and differentiation of human schistosomes by polymerase chain reaction. Exp. Parasitol. 2010, 124, 325-329. [CrossRef]

65. Kato-Hayashi, N.; Leonardo, L.R.; Arevalo, N.L.; Tagum, M.N.; Apin, J.; Agsolid, L.M.; Chua, J.C.; Villacorte, E.A.; Kirinoki, M.; Kikuchi, M.; et al. Detection of active schistosome infection by cell-free circulating DNA of Schistosoma japonicum in highly endemic areas in Sorsogon Province, the Philippines. Acta Trop. 2015, 141, 178-183. [CrossRef] [PubMed]

66. Driscoll, A.J.; Kyle, J.L.; Remais, J. Development of a novel PCR assay capable of detecting a single Schistosoma japonicum cercaria recovered from Oncomelania hupensis. Parasitology 2005, 131, 497-500. [CrossRef] [PubMed]

67. Lu, Z.X.; Xu, J.; Gong, W.; Luo, W.; Zhang, H.Q.; Rong, R.; Shi, C.J.; Xia, C.M. Detection of Schistosoma japonicum DNA by polymerase chain reaction. Chin. J. Zoonoses 2007, 23, 479-483. (In Chinese)

68. Fung, M.S.; Xiao, N.; Wang, S.; Carlton, E.J. Field evaluation of a PCR test for Schistosoma japonicum egg detection in low-prevalence regions of China. Am. J. Trop. Med. Hyg. 2012, 87, 1053-1058. [CrossRef]

69. Zhao, X.; Gu, K.; Zeng, Q.; Gao, L.; Cheng, D. Diagnostic value of SjR2 gene in colonic tissue from Schistosoma japonicum infected hosts. Med. Sci. Monit. 2019, 25, 427-435. [CrossRef]

70. Xu, J.; Rong, R.; Zhang, H.Q.; Shi, C.J.; Zhu, X.Q.; Xia, C.M. Sensitive and rapid detection of Schistosoma japonicum DNA by loop-mediated isothermal amplification (LAMP). Int. J. Parasitol. 2010, 40, 327-331. [CrossRef]

71. Xu, X.; Zhang, Y.; Lin, D.; Zhang, J.; Xu, J.; Liu, Y.M.; Hu, F.; Qing, X.; Xia, C.; Pan, W. Serodiagnosis of Schistosoma japonicum infection: Genome-wide identification of a protein marker, and assessment of its diagnostic validity in a field study in China Lancet Infect. Dis. 2014, 14, 489-497. [CrossRef]

72. Gobert, G.N.; Chai, M.; Duke, M.; McManus, D.P. Copro-PCR based detection of schistosoma eggs using mitochondrial DNA markers. Mol. Cell Probes 2005, 19, 250-254. [CrossRef]

73. Laha, T.; Brindley, P.J.; Smout, M.J.; Verity, C.K.; McManus, D.P.; Loukas, A. Reverse transcriptase activity and untranslated region sharing of a new RTE-like, non-long terminal repeat retrotransposon from the human blood fluke, Schistosoma japonicum. Int. J. Parasitol. 2002, 32, 1163-1174. [CrossRef]

74. Guo, J.J.; Zheng, H.J.; Xu, J.; Zhu, X.Q.; Wang, S.Y.; Xia, C.M. Sensitive and specific target sequences selected from retrotransposons of Schistosoma japonicum for the diagnosis of schistosomiasis. PLoS Negl. Trop. Dis. 2012, 6, e1579. [CrossRef]

75. Zhang, F.; Hou, M.; Chuan-Xin, Y.U.; Yang, K.; Yang, B.Y.; Zhang, W.Y.; Luo, X.F.; Chen, L.; Min-Jun, J.I. The use of nested PCR to monitor sentinel mice in aquatic areas infested with schistosomiasis japonica. J. Pathog. Biol. 2015, 10, 325-328. (In Chinese)

76. Xu, J.; Duan, Z.L.; Guan, Z.X.; Wang, Y.Y.; Lin, C.; Zhang, T.T.; Zhang, H.Q.; Qian, X.; Xia, C.M. Early detection of circulating DNA of Schistosoma japonicum in sentinel mice models. Exp. Parasitol. 2017, 176, 82-88. [CrossRef] [PubMed]

77. Liu, A.P.; Yang, Q.L.; Guo, J.J.; Jing, X.U.; Xia, C.M. DNA detection of low-intensity Schistosoma japonicum infection by nested-PCR assay in serum of host. Suzhou Univ. J. Med. Sci. 2010, 30, 915-917. (In Chinese)

78. Zhang, X.; He, C.C.; Liu, J.M.; Li, H.; Lu, K.; Fu, Z.Q.; Zhu, C.G.; Liu, Y.P.; Tong, L.B.; Zhou, D.B.; et al. Nested-PCR assay for detection of Schistosoma japonicum infection in domestic animals. Infect. Dis. Poverty 2017, 6, 86. [CrossRef] [PubMed]

79. Zeng, F.S.; He, L.; He, X.M.; Yang, J.; Qin, Z.Q. Nested-PCR assay for detection of Schistosoma japonicum. J. Trop. Dis. Parasitol. 2017, 15, 136-138. (In Chinese)

80. Tong, Q.B.; Lu, S.H.; Wang, T.P.; Chen, R.; Lou, D.; Zhuo, M.M. Utilization nested PCR to detect the infection of Schistosoma japonicum. Acta Parasitol. Med. Entomol. Sin. 2009, 16, 203-207. (In Chinese)

81. Bell, A.; Ranford-Cartwright, L. Real-time quantitative PCR in parasitology. Trends Parasitol. 2002, 18, 338. [CrossRef]

82. Williams, P.M.; Giles, T.; Tucker, A.; Winer, J.; Heid, C. Development and application of real-time quantitative PCR. Birkhäuser Boston. 1998, 1, 313-325. [CrossRef]

83. Gordon, C.A.; Gray, D.J.; Gobert, G.N.; Mcmanus, D.P. DNA amplification approaches for the diagnosis of key parasitic helminth infections of humans. Mol. Cell Probes 2011, 25, 143-152. [CrossRef] [PubMed]

84. Lier, T.; Simonsen, G.S.; Haaheim, H.; Hjelmevoll, S.O.; Vennervald, B.J.; Johansen, M.V. Novel real-time PCR for detection of Schistosoma japonicum in stool. Southeast Asian J. Trop. Med. Public Health 2006, 37, 257-264. [PubMed]

85. Lier, T.; Simonsen, G.S.; Wang, T.; Lu, D.; Haukland, H.H.; Vennervald, B.J.; Hegstad, J.; Johansen, M.V. Real-time polymerase chain reaction for detection of low-intensity Schistosoma japonicum infections in China. Am. J. Trop. Med. Hyg. 2009, 81, 428-432. [CrossRef]

86. He, P.; Gordon, C.A.; Williams, G.M.; Li, Y.; Wang, Y.; Hu, J.; Gray, D.J.; Ross, A.G.; Harn, D.; McManus, D.P. Real-time PCR diagnosis of Schistosoma japonicum in low transmission areas of china. Infect. Dis. Poverty 2018, 7, 8. [CrossRef] [PubMed]

87. Wu, H.W.; Qin, Y.F.; Chu, K.; Meng, R.; Liu, Y.; McGarvey, S.T.; Olveda, R.; Acosta, L.; Ji, M.J.; Fernandez, T.; et al. High prevalence of Schistosoma japonicum infection in water buffaloes in the Philippines assessed by real-time polymerase chain reaction. Am. J. Trop. Med. Hyg. 2010, 82, 646-652. [CrossRef] [PubMed]

88. Gordon, C.A.; Acosta, L.P.; Gray, D.J.; Olveda, R.M.; Jarilla, B.; Gobert, G.N.; Ross, A.G.; McManus, D.P. High prevalence of Schistosoma japonicum infection in carabao from samar province, the philippines: Implications for transmission and control. PLoS Negl. Trop. Dis. 2012, 6, e1778. [CrossRef]

89. Gordon, C.A.; Acosta, L.P.; Gobert, G.N.; Jiz, M.; Olveda, R.M.; Ross, A.G.; Gray, D.J.; Williams, G.M.; Harn, D.; Li, Y.; et al. High prevalence of Schistosoma japonicum and fasciola gigantica in bovines from northern samar, the philippines. PLoS Negl. Trop. Dis. 2015, 9, e0003108. [CrossRef] 
90. Gordon, C.A.; Acosta, L.P.; Gobert, G.N.; Olveda, R.M.; Ross, A.G.; Williams, G.M.; Gray, D.J.; Harn, D.; Li, Y.; McManus, D.P. Real-time PCR demonstrates high prevalence of Schistosoma japonicum in the philippines: Implications for surveillance and control. PLoS Negl. Trop. Dis. 2015, 9, e0003483. [CrossRef]

91. Gordon, C.A.; McManus, D.P.; Acosta, L.P.; Olveda, R.M.; Williams, G.M.; Ross, A.G.; Gray, D.J.; Gobert, G.N. Multiplex real-time PCR monitoring of intestinal helminths in humans reveals widespread polyparasitism in northern samar, the Philippines. Int. J. Parasitol. 2015, 45, 477-483. [CrossRef] [PubMed]

92. Lier, T.; Johansen, M.V.; Hjelmevoll, S.O.; Vennervald, B.J.; Simonsen, G.S. Real-time PCR for detection of low intensity Schistosoma japonicum infections in a pig model. Acta Trop. 2008, 105, 74-80. [CrossRef] [PubMed]

93. Qin, Y.F.; Liu, Y.; Xue-Li, D.U.; Meng, R.; Chu, K.; Min-Jun, J.I.; Kurtis, J.D.; Hai-Wei, W.U. Sensitivity of SYBR green real-time copro-PCR on detection of Schistosoma japonicum infection. J. Pathog. Biol. 2009, 4, 432-435. (In Chinese)

94. Van Dorssen, C.F.; Gordon, C.A.; Li, Y.; Williams, G.M.; Wang, Y.; Luo, Z.; Gobert, G.N.; You, H.; McManus, D.P.; Gray, D.J. Rodents, goats and dogs-Their potential roles in the transmission of schistosomiasis in China. Parasitology 2017, 144, 1633-1642. [CrossRef]

95. Dang-Trinh, M.A.; Angeles, J.M.M.; Moendeg, K.J.; Macalanda, A.M.C.; Higuchi, L.; Oto, C.; Kirinoki, M.; Chigusa, Y.; Kawazu, S.I. Utilization of real time PCR for the assessment of egg burden in the organs of Schistosoma japonicum experimentally infected mice. Exp. Parasitol. 2018, 189, 61-65. [CrossRef]

96. Fornillos, R.J.C.; Sato, M.A.O.; Tabios, I.K.B.; Sato, M.; Leonardo, L.R.; Chigusa, Y.; Minamoto, T.A.O.; Kikuchi, M.; Legaspi, E.R.; Fontanilla, I.K.C. Detection of Schistosoma japonicum and Oncomelania hupensis quadrasi environmental DNA and its potential utility to schistosomiasis japonica surveillance in the Philippines. PLoS ONE 2019, 14, e0224617. [CrossRef]

97. Li, Z.; Liang, B.; Zhao, Y.Y.; Huang, L.; Wang, Y.F. Fluorescent quantitative real-time PCR for detection of Schistosoma japonicum. Chin. J. Parasitol. Parasit. Dis. 2008, 26, 299-303. (In Chinese)

98. Zhou, L.; Tang, J.; Zhao, Y.; Gong, R.; Lu, X.; Gong, L.; Wang, Y. A highly sensitive Taqman real-time PCR assay for early detection of schistosoma species. Acta Trop. 2011, 120, 88-94. [CrossRef]

99. Wang, B.J.; Wang, W.B.; Zhou, X.; Chen, Y.Q.; Zhang, J.; Liu, C.C.; Liang, Y.S.; Hong-Xiang, Z. Fluorescent quantitative real-time PCR for quantitative detection of Schistosoma japonicum cercariae in water. Chin. J. Zoonoses 2011, 27, 1075-1081. (In Chinese)

100. Kongklieng, A.; Kaewkong, W.; Intapan, P.M.; Sanpool, O.; Janwan, P.; Thanchomnang, T.; Lulitanond, V.; Sri-Aroon, P.; Limpanont, Y.; Maleewong, W. Molecular differentiation of Schistosoma japonicum and Schistosoma mekongi by real-time PCR with high resolution melting analysis. Korean J. Parasitol. 2013, 51, 651-656. [CrossRef]

101. Li, J.; Zhao, G.H.; Lin, R.; Blair, D.; Sugiyama, H.; Zhu, X.Q. Rapid detection and identification of four major schistosoma species by high-resolution melt (HRM) analysis. Parasitol. Res. 2015, 114, 4225-4232. [CrossRef] [PubMed]

102. Thanchomnang, T.; Intapan, P.; Sri-Aroon, P.; Lulitanond, V.; Janwan, P.; Sanpool, O.; Maleewong, W. Molecular detection of Schistosoma japonicum in infected snails and mouse faeces using a real-time PCR assay with fret hybridisation probes. Mem. Inst. Oswaldo Cruz 2011, 106, 831-836. [CrossRef] [PubMed]

103. Guan, W.; Jing, X.; Liang, S.; Sun, H.; Dong, L.L.; Xia, C.M. Quantificational detection of Schistosoma japonicum DNA in serum of the host and assessment of infectiosity by real-time pcr. Chin. J. Zoonoses 2014, 30, 263-267. (In Chinese) [CrossRef]

104. Xu, M.Z.; Wen, L.; Shen, X.J.; Liao, Y.; Tian, B. RT-PCR was used to monitor Schistosoma japonicum cercariae on the water surface in the reservoir area of Xiangjiang Changsha comprehensive hub project from 2016 to 2017. Pract. Prev. Med. 2021, 28, 837-839. (In Chinese)

105. Worrell, C.; Xiao, N.; Vidal, J.E.; Chen, L.; Zhong, B.; Remais, J. Field detection of Schistosoma japonicum cercariae in environmental water samples by quantitative PCR. Appl. Environ. Microbiol. 2011, 77, 2192-2195. [CrossRef]

106. Ben-Jing, W.; Wen-Bo, W.; Xia, Z.; You-Sheng, L.; Hong-Xiang, Z. Establishment eraly diganostic method for Schistosoma japonicum infetion based on mice model. Beijing Forum Trop. Med. Parasitol. 2011. (In Chinese)

107. Pomari, E.; Piubelli, C.; Perandin, F.; Bisoffi, Z. Digital PCR: A new technology for diagnosis of parasitic infections. Clin. Microbiol. Infect. 2019, 25, 1510-1516. [CrossRef]

108. Weerakoon, K.G.; Gordon, C.A.; Gobert, G.N.; Cai, P.; McManus, D.P. Optimisation of a droplet digital PCR assay for the diagnosis of Schistosoma japonicum infection: A duplex approach with DNA binding dye chemistry. J. Microbiol. Methods 2016, 125, 19-27. [CrossRef]

109. Weerakoon, K.G.; Gordon, C.A.; Cai, P.; Gobert, G.N.; Duke, M.; Williams, G.M.; McManus, D.P. A novel duplex ddPCR assay for the diagnosis of schistosomiasis japonica: Proof of concept in an experimental mouse model. Parasitology 2017, 144, 1005-1015. [CrossRef]

110. Weerakoon, K.G.; Gordon, C.A.; Williams, G.M.; Cai, P.; Gobert, G.N.; Olveda, R.M.; Ross, A.G.; Olveda, D.U.; McManus, D.P. Droplet digital PCR diagnosis of human schistosomiasis: Parasite cell-free DNA detection in diverse clinical samples. J. Infect. Dis. 2017, 216, 1611-1622. [CrossRef]

111. Cai, P.; Weerakoon, K.G.; Mu, Y.; Olveda, R.M.; Ross, A.G.; Olveda, D.U.; McManus, D.P. Comparison of kato katz, antibody-based elisa and droplet digital PCR diagnosis of schistosomiasis japonica: Lessons learnt from a setting of low infection intensity. PLoS Negl. Trop. Dis. 2019, 13, e0007228. [CrossRef] [PubMed]

112. Notomi, T.; Okayama, H.; Masubuchi, H.; Yonekawa, T.; Watanabe, K.; Amino, N.; Hase, T. Loop-mediated isothermal amplification of DNA. Nucleic Acids Res. 2000, 28, E63. [CrossRef] [PubMed] 
113. García-Bernalt, J.D.; Fernández-Soto, P.A.; Febrer-Sendra, B.; Crego-Vicente, B.; Muro, A.A. Loop-mediated isothermal amplification in schistosomiasis. J. Clin. Med. 2021, 10, 511. [CrossRef] [PubMed]

114. Avendaño, C.A.; Patarroyo, M.A. Loop-mediated isothermal amplification as point-of-care diagnosis for neglected parasitic infections. Int. J. Mol. Sci. 2020, 21, 7981. [CrossRef]

115. Tomita, N.; Mori, Y.; Fau-Kanda, H.; Notomi, T. Loop-mediated isothermal amplification (LAMP) of gene sequences and simple visual detection of products. Nat. Protoc. 2008, 3, 877-882. [CrossRef]

116. Hsieh, K.; Mage, P.L.; Csordas, A.T.; Eisenstein, M.; Soh, H.T. Simultaneous elimination of carryover contamination and detection of DNA with uracil-DNA-glycosylase-supplemented loop-mediated isothermal amplification (UDG-LAMP). Chem. Commun. 2014, 50, 3747-3749. [CrossRef]

117. Ma, C.; Wang, F.; Wang, X.; Han, L.; Jing, H.; Zhang, H.; Shi, C. A novel method to control carryover contamination in isothermal nucleic acid amplification. Chem. Commun. 2017, 53, 10696-10699. [CrossRef]

118. Deng, P.C.; Zhang, R.J.; Liang, Y.; Zhang, Y.K.; Yang, Q.L. Detection of Schistosoma japonicum-Infected Oncomelania hupensis by loop-Mediated isothermal amplification. Chin. J. Vet. Sci. 2009, 29, 1017-1018+1027. (In Chinese)

119. Yang, Q.L.; Xu, L.F.; Zhang, Y.K.; Wang, K.G. Detection of Schistosoma japonicum cercaria DNA by loop-mediated isothermal amplification. Chin. J. Schistosomiasis Control 2008, 20, 209-211. (In Chinese)

120. Yu, C.X.; Yin, X.R.; Hua, W.Q.; Gao, Q. Establishment of loop mediated isothermal DNA amplification for identifying oncomelania snails infected with Schistosoma japonicum. J. Pathog. Biol. 2008, 3, 661-664. (In Chinese)

121. Yu, C.X.; Yin, X.R.; Wang, J.; Song, L.J.; Qian, C.Y.; Wu, F.; He, W.; Zhang, W. Creation and use of a LAMP kit to rapidly detect snails infected with Schistosoma japonicum. J. Pathog. Biol. 2011, 6, 121-124. (In Chinese)

122. Feng, J.T.; Xing, W.W.; Sun, K.; Yu, X.L.; Luo, Z.H.; Mao, J.W.; Xu, D.G. Application of visible loop-mediated isothermal amplification (LAMP) technologies in detecting oncomelania infected with Schistosoma japonicum. Mil. Med. Sci. 2016, 40, 133-136. (In Chinese)

123. Xu, J.; Guan, Z.X.; Zhao, B.; Wang, Y.Y.; Cao, Y.; Zhang, H.Q.; Zhu, X.Q.; He, Y.K.; Xia, C.M. DNA detection of Schistosoma japonicum: Diagnostic validity of a lamp assay for low-intensity infection and effects of chemotherapy in humans. PLoS Negl. Trop. Dis. 2015, 9, e0003668. [CrossRef] [PubMed]

124. Wang, C.; Chen, L.; Yin, X.; Hua, W.; Hou, M.; Ji, M.; Yu, C.; Wu, G. Application of DNA-based diagnostics in detection of schistosomal DNA in early infection and after drug treatment. Parasites Vectors 2011, 4, 164. [CrossRef]

125. Wang, C.; Chuan-Xin, Y.U.; Min-Jun, J.I.; Song, L.J.; Yin, X.R.; Qian, C.Y.; Wang, J.; Guan-Ling, W.U. Use of loop-mediated isothermal amplification (LAMP) to detect whole blood samples infected with Schistosoma japonicum. J. Pathog. Biol. 2010, 5, 749-753. (In Chinese)

126. Xiong, C.R.; Yin, X.R.; Song, L.J.; Shen, S.; Wang, J.; Gao, G.; Liu, Q.; Yu, C.X.; Yang, K. Comparison of the effectiveness of loop-mediated isothermal DNA amplification (LAMP) and mocroscopic dissection at detecting snails infected with Schistosoma japonicum. J. Pathog. Biol. 2014, 9, 1084-1087. (In Chinese)

127. Li, Y.L.; Dang, H.; Guo, S.Y.; Cao, C.L.; Lü, S.; Xu, J.; Li, S.Z. National surveillance of Oncomelania hupensis in China. Chin. J. Schistosomiasis Control 2021, 33, 127-132. (In Chinese) [CrossRef]

128. Piepenburg, O.; Williams, C.H.; Stemple, D.L.; Armes, N.A. DNA detection using recombination proteins. PLoS Biol. 2006, 4, e204. [CrossRef]

129. Li, J.A.; Macdonald, J.A.; von Stetten, F. Review: A comprehensive summary of a decade development of the recombinase polymerase amplification. Analyst 2018, 144, 31-67. [CrossRef]

130. Lobato, I.M.; O'Sullivan, C.K. Recombinase polymerase amplification: Basics, applications and recent advances. Trends Analyt. Chem. 2018, 98, 19-35. [CrossRef]

131. Wang, S.L.; Wang, L.P.; Wu, L.L.; Li, Y.L.; Zhang, L.J.; Lü, S.; Xu, J. Diagnostic value of nucleic acid detection in schistosomiasis japonica: A meta-analysis. Chin. J. Schistosomiasis Control 2020, 32, 15-22. (In Chinese) [CrossRef]

132. Song, Z.; Ting, L.; Kun, Y.; Wei, L.; Jian-Feng, Z.; Li-Chuan, G.; Yan-Hong, L.; Yang, D.; Qing-Jie, Y.; Hai-Tao, Y. Establishment of a recombinase-aided isothermal amplification technique to detect Schistosoma japonicum specific gene fragments. Chin. J. Schistosomiasis Control 2018, 30, 273-277. (In Chinese) [CrossRef]

133. Zhao, S.; Liu, Y.H.; Li, T.; Li, W.; Zhang, J.F.; Guo, L.C.; Ying, Q.J.; Yang, H.T.; Yang, K. Rapid detection of Schistosoma japonicum specific gene fragment by recombinase aided isothermal amplification combined with fluorescent probe. Chin. J. Parasitol. Parasit. Dis. 2019, 37, 23-27. (In Chinese) [CrossRef]

134. Ting, L.; Yan-Hong, L.; Song, Z.; Chun-Rong, X.; Xuan, D.; Jian-Feng, Z.; Wei, L.; Qing-Jie, Y.; Kun, Y. Rapid detection of Schistosoma japonicum-infected snails with recombinase-aided isothermal amplification assay. Chin. J. Schistosomiasis Control 2019, 31, 109-114. (In Chinese) [CrossRef]

135. Dong, X.; Xiong, C.R.; Li, T.; Zhao, S.; Zhang, J.F.; Li, W.; Yang, K. Early detection of Oncomelania snails infected eith Schistosoma japonicun by recombinase aided amplification. J. Pathog. Biol. 2019, 14, 1245-1249. (In Chinese) [CrossRef]

136. Ye, Y.Y.; Zhao, S.; Liu, Y.H.; Zhang, J.F.; Xiong, C.R.; Ying, Q.J.; Yang, K. Establishment of a nucleic acid dipstick test for detection of Schistosoma japonicum specific gene fragments based on the recombinase-aided isothermal amplification assay. Chin. $J$ Schistosomiasis Control 2021, 33, 334-338. (In Chinese) [CrossRef] 
137. Ye, Y.Y.; Zhao, S.; Liu, Y.H.; Bi, N.N.; Dong, X.; Xiong, C.R.; Zhu, H.R.; Tang, F.; Wang, X.Y.; Zhang, J.F.; et al. Performance of a recombinase-aided amplification assay for detection of Schistosoma japonicum infections in Oncomelania hupensis. Chin. J. Schistosomiasis Control 2021, 33, 185-188. (In Chinese) [CrossRef]

138. Deng, W.P.; Xu, B.; Hong, Q.H.; Wang, S.L.; Lv, C.; Li, Y.L.; Song, S.P.; Chen, J.H.; Xu, J.; Li, S.Z. Establishment of the detection method for Schistosoma japonicum by recombinase polymerase amplification combined with electrochemical DNA biosensor. Chin. J. Parasitol. Parasit. Dis. 2020, 38, 42-48. (In Chinese) [CrossRef]

139. Wang, S.L.; Deng, W.P.; Li, Y.L.; Wang, L.P.; Zhang, L.J.; Lv, S.; Xu, J. Establishment of recombinase polymerase amplification technique for rapid detection of Schistosoma japonicum nucleic acid. Chin. J. Parasitol. Parasit. Dis. 2020, 38, 293-298. (In Chinese) [CrossRef]

140. Deng, W.P.; Hong, Q.H.; Xu, B.; Wang, S.L.; Wang, L.P.; Xu, J.; Hu, W.; Zhou, X.N. Development and preliminary evaluation of a rapid visualization detection method for circulating nucleic acids of Schistosoma japonicum based on RPA-LFD. Chin. J. Parasitol. Parasit. Dis. 2020, 38, 286-292. (In Chinese)

141. Stothard, J.R.; Stanton, M.C.; Bustinduy, A.L.; Sousa-Figueiredo, J.C.; Van Dam, G.J.; Betson, M.; Waterhouse, D.; Ward, S.; Allan, F.; Hassan, A.A.; et al. Diagnostics for schistosomiasis in Africa and Arabia: A review of present options in control and future needs for elimination. Parasitology 2014, 141, 1947-1961. [CrossRef] [PubMed]

142. Silva, M.A.; Medeiros, Z.; Soares, C.R.; Silva, E.D.; Miranda-Filho, D.B.; Melo, F.L. A comparison of four DNA extraction protocols for the analysis of urine from patients with visceral leishmaniasis. Rev. Soc. Bras. Med. Trop. 2014, 47, 193-197. [CrossRef] [PubMed]

143. Van den Broeck, F.; Geldof, S.; Polman, K.; Volckaert, F.A.M.; Huyse, T. Optimal sample storage and extraction procotols for reliable multilocus genotyping of the human parasite Schistosoma mansoni. Infect. Genet. Evol. 2011, 11, 1413-1418. [CrossRef] [PubMed]

144. Papaiakovou, M.A.; Pilotte, N.; Baumer, B.; Grant, J.; Asbjornsdottir, K.; Schaer, F.; Hu, Y.; Aroian, R.; Walson, J.; Williams, S.A. A comparative analysis of preservation techniques for the optimal molecular detection of hookworm DNA in a human fecal specimen. PLoS Negl. Trop. Dis. 2018, 12, e0006130. [CrossRef] [PubMed]

145. García-Bernalt Diego, J.; Fernández-Soto, P.A.; Crego-Vicente, B.; Alonso-Castrillejo, S.; Febrer-Sendra, B.; Gómez-Sánchez, A.; Vicente, B.; López-Abán, J.; Muro, A. Progress in loop-mediated isothermal amplification assay for detection of Schistosoma mansoni DNA: Towards a ready-to-use test. Sci. Rep. 2019, 9, 14744. [CrossRef] [PubMed]

146. Rahman, M.A.; Sassa, M.; Parvin, N.; Islam, M.R.; Yajima, A.A.; Ota, E. Diagnostic test accuracy for detecting Schistosoma japonicum and S. mekongi in humans: A systematic review and meta-analysis. PLoS Negl. Trop. Dis. 2021, 15, e0009244. [CrossRef] [PubMed]

147. Land, K.A.; Boeras, D.I.; Chen, X.S.; Ramsay, A.R.; Peeling, R.W. Reassured diagnostics to inform disease control strategies, strengthen health systems and improve patient outcomes. Nat. Microbiol. 2019, 4, 46-54. [CrossRef]

148. Zhang, H.; Xu, Y.; Fohlerova, Z.; Chang, H.; Iliescu, C.; Neuzil, P. Lamp-on-a-chip: Revising microfluidic platforms for loopmediated DNA amplification. Trends Analyt. Chem. 2019, 113, 44-53. [CrossRef]

149. Shang, Y.; Sun, J.; Ye, Y.; Zhang, J.; Zhang, Y.; Sun, X. Loop-mediated isothermal amplification-based microfluidic chip for pathogen detection. Crit. Rev. Food Sci. Nutr. 2020, 60, 201-224. [CrossRef]

150. Ye, X.; Fang, X.; Li, X.; Kong, J. Gold nanoparticle-mediated nucleic acid isothermal amplification with enhanced specificity. Anal Chim. Acta 2018, 1043, 150-157. [CrossRef] 